\title{
Modelling Lyssavirus Infections in Human Stem Cell-Derived Neural Cultures
}

\author{
Vinod Sundaramoorthy ${ }^{1}{ }^{\mathbb{D}}$, Nathan Godde ${ }^{1}$, Ryan J. Farr ${ }^{1}$, Diane Green ${ }^{1}$, John M. Haynes ${ }^{2}{ }^{\mathbb{D}}$, \\ John Bingham ${ }^{1}$, Carmel M. O'Brien ${ }^{3,4,+}$ and Megan Dearnley ${ }^{1, *,+}$ \\ 1 Commonwealth Scientific and Industrial Research Organisation (CSIRO), Australian Animal Health \\ Laboratory (AAHL), East Geelong, VIC 3219, Australia; vinod.sundaramoorthy@csiro.au (V.S.); \\ nathan.godde@csiro.au (N.G.); ryan.farr@csiro.au (R.J.F.); diane.green@csiro.au (D.G.); \\ john.bingham@csiro.au (J.B.) \\ 2 Monash Institute of Pharmaceutical Sciences, 399 Royal Parade, Parkville, VIC 3052, Australia; \\ john.haynes@monash.edu \\ 3 CSIRO Manufacturing, Research Way, Clayton, VIC 3168, Australia; carmel.o'brien@csiro.au \\ 4 Australian Regenerative Medicine Institute, Monash University, Clayton, VIC 3168, Australia \\ * Correspondence: megan.dearnley@csiro.au \\ + These authors contributed equally to the work.
}

Received: 28 December 2019; Accepted: 20 March 2020; Published: 25 March 2020

\begin{abstract}
Rabies is a zoonotic neurological infection caused by lyssavirus that continues to result in devastating loss of human life. Many aspects of rabies pathogenesis in human neurons are not well understood. Lack of appropriate ex-vivo models for studying rabies infection in human neurons has contributed to this knowledge gap. In this study, we utilize advances in stem cell technology to characterize rabies infection in human stem cell-derived neurons. We show key cellular features of rabies infection in our human neural cultures, including upregulation of inflammatory chemokines, lack of neuronal apoptosis, and axonal transmission of viruses in neuronal networks. In addition, we highlight specific differences in cellular pathogenesis between laboratory-adapted and field strain lyssavirus. This study therefore defines the first stem cell-derived ex-vivo model system to study rabies pathogenesis in human neurons. This new model system demonstrates the potential for enabling an increased understanding of molecular mechanisms in human rabies, which could lead to improved control methods.
\end{abstract}

Keywords: rabies; lyssavirus; stem cell-derived neurons; ex-vivo models; viral pathogenesis; trans-synaptic axonal trafficking; chemokine and cytokine response; neuronal apoptosis

\section{Introduction}

The genus Lyssavirus, belonging to family Rhabdoviridae, consists of a group of negative strand RNA viruses capable of causing rabies-like disease in humans and other mammals [1]. Rabies virus belongs to the prototype Rabies lyssavirus species and usually transmitted between terrestrial carnivore species, to a lesser extent bat species and humans [2]. In addition, there are 15 other officially recognized species within the Lyssavirus genus, most of which have been isolated from bats [1,3,4]. Although effective vaccination is available for post-exposure prophylaxis (PEP), rabies still persists as a global health issue, accounting for a significant number of preventable deaths [5-7]. The death rate from rabies is particularly high in developing countries due to poor access to PEP and many of the victims are children under the age of 15 years [6-8].

Victims are usually infected through the bite of infected animals. The virus then invades the neuromuscular junctions at the site of bite entering the host nervous system [5]. Once inside the 
neuronal axons, the virus uses anterograde trafficking to spread through the nervous system until it reaches the brain $[9,10]$, resulting in encephalitis. Viral infections in the central nervous system (CNS) present significant challenges due to its separation from the peripheral immune system by the blood brain barrier (BBB). CNS resident cells, including neurons, secrete a variety of chemokines to stimulate infiltration of immune cells into the CNS for effective viral clearance [11-15], which is aided by immune-modulatory cells such as microglia and astrocytes [16,17]. However, such immune response is highly ineffective in clearing rabies virus [18]. This is due to the ability of rabies virus to inhibit innate and adaptive immune responses using diverse strategies, including inhibition of interferon response by phosphoprotein [19-21] and virus-induced apoptosis of immune $\mathrm{T}$ cells [22-24]. While immune-mediated viral clearance is impeded in rabies infection, there is upregulation of specific chemokines and cytokines, linked with inflammation and enhancement of blood-brain barrier permeability, which could be detrimental to the nervous system [25-28]. In addition, rabies infection does not typically result in the loss of neurons or neuronal apoptosis in the nervous system $[29,30]$. In fact, efficient rabies infection restricts neuronal apoptosis to enhance viral replication in neurons $[18,31]$. Despite the lack of neuronal loss, rabies infection causes severe neurological dysfunction in the host, resulting in clinical features such as paralysis, behavioral, and cognitive deficits [32-34]. This indicates that rabies infection could induce neuronal dysfunction rather than killing the neurons. However, these key pathogenic mechanisms in rabies are yet to be examined in ex-vivo models of human neurons.

Studies on rabies pathogenesis to date have predominantly relied on animal models. Mouse models and primary mouse neuronal cultures have been the preferred source to investigate rabies pathogenesis in-vivo and in-vitro, respectively. These model systems have identified several key pathogenic mechanisms, which have greatly improved our understanding of rabies [5,10,35-37]. However, there are ethical and practical constraints which can limit the investigation of upstream neuronal pathogenic mechanisms in living animals and in primary neurons. Ideally, development of a human neuronal model system, which could be used in concert with current animal models, would greatly assist the investigation of viral pathogenesis in humans. In addition, a species-specific model system would significantly contribute towards better understanding features of viral pathogenesis in human infection, such as viral adaptations at a molecular level that enable host-switching for efficient infection in the human nervous system. While there have been previous attempts to utilize such human neuronal model systems [38,39], stem cell technologies have not yet been explored to model rabies pathogenesis. Such technologies could provide an ethically renewable, high throughput platform for screening potential therapeutics against human rabies.

The advancement of stem cell technology has greatly enabled the generation of ex-vivo models of human CNS for studying neurodegenerative diseases and infections. This includes successful modelling of neurotropic viral infections such as herpes simplex virus (HSV) [40], varicella zoster virus (VSV) [41], La Crosse virus [42] and flaviviruses such as Zika virus [43,44], West Nile virus [45], dengue virus [44,46], and Japanese encephalitis virus (JEV) [47] in stem cell-derived human neural cultures. Such advances are enabled by efficient protocols for specific differentiation of embryonic stem cells (ESC) and induced pluripotent stem cells (iPSC) into functional neural lineage cultures representative of CNS resident cells [48]. Although ESC and iPSC have similar differentiation capacity [49,50], differences in origin may influence neuronal modelling [51-56] and susceptibility to viral infections [57]. Hence, investigation into disease modelling using stem cell-derived neural cultures should consider the differences in ESC or iPSC origin of these model systems.

In this study, we generated and characterized human stem cell-derived neural model systems for the study of rabies pathogenesis. We differentiated human ESC- and iPSC-derived neuronal precursor cells (hNPCs) into forebrain-type neural cultures consisting of mature neurons and astrocytes. Using these neural cultures, we studied the pathogenesis of different lyssavirus strains, including laboratory-adapted CVS-11 rabies virus and several field strains of lyssavirus isolated from infected dogs or bats. In these studies, we demonstrate efficient infection of both ESC- and iPSC-derived human 
neurons with all virus strains. We next examined whether these ex-vivo models consisting of stem cell-derived human neurons would reproduce key pathogenic mechanisms associated with rabies. We show that, consistent with the existing knowledge of rabies pathogenesis, lyssavirus infection in human neural cell cultures did not result in the activation of neuronal apoptosis. However, infection with CVS-11 and a field rabies virus strain resulted in the upregulation of a specific subset of cytokines and chemokines involved in enhancing BBB permeability and neuroinflammation. Additionally, we generated an ex-vivo model using microfluidics to study the trans-synaptic trafficking of rabies virus along the human neuronal network. This novel ex-vivo model system demonstrated axonal trafficking of rabies virus in human neuronal network and highlighted differences in axonal transmission dynamics between laboratory-adapted CVS-11 and a field rabies virus strain. This describes a novel ex-vivo model system in which to undertake a controlled study of axonal trafficking of rabies virus between interconnected human neurons. In summary, this study reports the first detailed characterization of lyssaviruses infection of in-vitro differentiated human neural cultures. This could serve as a new model system for future studies of the biological and immunological responses of human neurons to lyssaviruses, complimenting the existing in-vivo and in-vitro animal models of rabies.

\section{Materials and Methods}

\subsection{Ethics Statement}

Human ethics: All work using human iPSC and ESC pluripotent cell (hPSC) lines and their derivative neural lineage cell types, was carried out in accordance with Australia's National Health and Medical Research Council (NHMRC) 'National Statement on Ethical Conduct in Human Research' (2007, updated 2018), the 'Australian Code for the Responsible Conduct of Research' (2007, updated 2018), and with approvals from the Monash University Human Research Ethics Committee for parental pluripotent cell lines (20060009880 04/11/2006, 2015000129 04/02/2015), and from the Commonwealth Scientific and Industrial Research Organization (CSIRO) Health and Medical Research Ethics Committee for human neural precursor cell lines (LR 16/2017 29/11/2017).

Animal ethics: All experiments involving suckling mouse for rabies virus amplification in this study were reviewed and approved by the Animal Ethics Committee (AEC) of the Australian Animal Health Laboratory (AAHL) (approval \#1605, 05/04/2013), following the Australian National Health and Medical Research Council Code of Practice for the Care and Use of Animals for Scientific Purposes.

\subsection{Cell Culture}

\subsubsection{Generation of Human Neural Precursor Cells (hNPCs)}

The iPSC line HDF51i-509, previously derived by Sendai reprogramming of human dermal fibroblast (HDF) cells [58], was kindly provided under materials transfer agreement by Prof. Jeanne Loring (The Scripps Research Institute, La Jolla, CA, USA). The hESC line WA09 [59] (H9), was provided under materials transfer agreement with WiCell Research Institute, Madison, WI, USA, http://www.wicell.org/. Differentiation of parental HDF51i-509 and H9 pluripotent cell (hPSC) lines to neural stem and progenitor precursors (hNPCs) was performed, as described previously [60]. Briefly, hPSCs maintained in Essential $8^{\mathrm{TM}}$ (E8) medium on Geltrex ${ }^{\mathrm{TM}}$-coated tissue cultureware [61] were harvested with Accutase (Thermofisher Scientific, Waltham, MA, USA) and transferred to AggreWell $^{\mathrm{TM}} 800$ culture plates (STEMCELL Technologies, Vancouver, BC, Canada) for the formation of uniform aggregate embryoid bodies (EBs) [62], in serum-free NeuroCult ${ }^{\mathrm{TM}}$ NS-A human Basal Medium supplemented with, $20 \mathrm{ng} / \mathrm{mL}$ human recombinant bFGF, $20 \mathrm{ng} / \mathrm{mL}$ human recombinant EGF (Peprotech, Rocky Hill, NJ, USA), and 500 ng/mL human noggin (R\&D systems, Minneapolis, $\mathrm{MN}$ ) [63-66]. EBs were transferred following 5 days of the above neural lineage induction culture to ultra-low attachment culture plates (Corning, NY, USA) for neurosphere induction in the same medium conditions. Neurosphere suspension cultures were expanded for a further 9 days with medium 
replenished every 2 days, then dissociated and seeded to tissue cultureware coated at $1 \mu \mathrm{g} / \mathrm{cm}^{2}$ with Englebreth-Holm-Swarm murine sarcoma basement membrane laminin (Sigma-Aldrich, St. Louis, MO, USA, 10 $\mu \mathrm{g} / \mathrm{mL}$ in 1:1 DMEM/Hams F12 (DMEM/F12), Thermofisher Scientific, Waltham, MA, USA), expanding the hNPCs as monolayer cultures in the above mitogenic media without noggin supplement $[67,68]$. Renewing neural stem cell cultures were transferred after three passages to STEMdiff ${ }^{\mathrm{TM}}$ Neural Progenitor Medium (NPM), (STEMCELL Technologies, Vancouver, BC, Canada) for adherent maintenance culture. Established hNPC lines were successfully maintained from each parental derivation for up to 15 passages in STEMdiff ${ }^{\mathrm{TM}} \mathrm{NPM}$, cryopreserved in STEMdiff ${ }^{\mathrm{TM}} \mathrm{NPM}$ Freeze Medium, and thawed as an expanding population of hNPCs.

\subsubsection{Differentiation of hNPCs}

HDF51i-509-NPCs and H9-NPCs were differentiated in-vitro according to an adapted protocol (STEMCELL Technologies, Vancouver, BC, Canada) for neural lineage induction by mitogen withdrawal [69] and maturation in a physiological neuronal basal medium [70]. Briefly, hNPCs were seeded at 15,000-25,000 cells $/ \mathrm{cm}^{2}$ in 24 well tissue culture plates coated with $15 \mu \mathrm{g} / \mathrm{mL}$ poly-L-ornithine (Sigma-Aldrich, St. Louis, MO, USA) in phosphate buffered saline (PBS) and $10 \mu \mathrm{g} / \mathrm{mL}$ laminin (Sigma-Aldrich, St. Louis, MO, USA) in DMEM/F12 $\left(1 \mu \mathrm{g} / \mathrm{cm}^{2}\right.$, Thermofisher Scientific, Waltham, MA, USA), then expanded for $\sim 2$ days in STEMDiff ${ }^{\mathrm{TM}} \mathrm{NPM}$ at $37^{\circ} \mathrm{C}$ in an atmosphere of $5 \% \mathrm{CO}_{2}$ in air until at $40-50 \%$ confluency. Neural differentiation was initiated by replacing $50 \% v / v$ of the culture medium with BrainPhys ${ }^{\mathrm{TM}}$ neural medium supplemented with $2 \% v / v$ Neurocult $^{\mathrm{TM}}$ SM1 Neuronal Supplement, $1 \% v / v$ N2 Supplement-A (STEMCELL Technologies, Vancouver, BC, Canada), $20 \mathrm{ng} / \mathrm{mL}$ human recombinant brain-derived neurotrophic factor (BDNF), $20 \mathrm{ng} / \mathrm{mL}$ human recombinant glial cell line-derived neurotrophic factor (GDNF) (Peprotech, Rocky Hill, NJ, USA), 1 mM dibutyrl cyclic-AMP sodium salt (Sigma-Aldrich, St. Louis, MO, USA), $200 \mathrm{nM}$ ascorbic acid (STEMCELL Technologies, Vancouver, BC, Canada), making complete BrainPhys ${ }^{\mathrm{TM}}$ neural medium. HNPC differentiation and neural maturation was continued for up to 35 days with $50 \% v / v$ complete BrainPhys ${ }^{\mathrm{TM}}$ media changes each 2-3 days.

\subsection{Calcium Imaging}

Calcium imaging was performed on both ESC- and iPSC-derived neural cultures as described previously [71], after at least 21 days of hNPC differentiation. Briefly, neural cultures were loaded, in media, with $5 \mu \mathrm{M}$ Fura-2 AM (ABCAM, Cambridge, UK) for $30-40$ min at $37^{\circ} \mathrm{C}$ under $5 \% \mathrm{CO}_{2}$ in air. For imaging, cultures were incubated with HEPES buffered salt solution (consisting of $\mathrm{NaCl}, 145 \mathrm{mM}$; $\mathrm{KCl}, 5 \mathrm{mM}$; $\mathrm{MgSO}_{4}, 1 \mathrm{mM}$; HEPES, $10 \mathrm{mM}$; $\mathrm{CaCl}_{2}, 2 \mathrm{mM}$; glucose, $10 \mathrm{mM}$, containing $0.1 \%$ bovine serum albumin, at $\mathrm{pH}$ 7.4) and imaged using Nikon TE2000U microscope (Nikon, Minato City, Tokyo, Japan) with $20 \times$ objective and a glass stage heated to $37^{\circ} \mathrm{C}$. A DG4 (Sutter, Novato, CA, USA) was used to illuminate cells with light at 340 and $380 \mathrm{~nm}$. Fluorescence emission at $510 \mathrm{~nm}$ was recorded every 1-2 s. Cells morphologically characteristic of neurons, with fine axonal projections, were selected as regions of interest (ROI) for intensity measurement and analysis. Background emission was subtracted from each image and 340/380 ratios of the resultant intensity emission values at each time point were obtained. Drugs such as ATP, glutamate, or dopamine (Sigma-Aldrich, St. Louis, MO, USA) were added to the cell cultures at $100 \mu \mathrm{m}$ during imaging to stimulate calcium influx. The cultures were washed with HEPES buffer between each drug treatment and allowed enough time for cells to reach basal excitation state before subsequent stimulation.

\subsection{Virus Stock Amplification and Quantification}

Laboratory-adapted CVS-11 strain was passaged and amplified in Neuro-2a cells (ATCC: CCL131, Manassas, VA, USA). Original lyssavirus field strains such as an Australian bat lyssavirus strain isolated from an infected horse (H.ABLV), a Canadian silver-head bat rabies virus (SHBRV), and a rabies virus strain isolated from an infected dog in Zimbabwe (Z.Dog) were amplified by intracerebral 
inoculation in suckling mouse brains (Swiss mice). After this, $10 \%$ mouse brain homogenates in $0.05 \mathrm{M}$ phosphate buffered saline (PBSA) containing the virus were used to infect Neuro-2a cells for further amplification. The viral strains were subjected to fewer than 3 passages in Neuro-2a cells during amplification. The viral titer of cell culture supernatants were determined by titration assays on BHK-21 cells (CSL, Parkville, Vic, Australia) by direct fluorescent antibody test. Briefly, serial 10-fold dilutions of viral suspensions were prepared in cell culture media and were added to 96 well plates (4 replicates each), followed by BHK cell suspensions. The cells were then incubated at $37^{\circ} \mathrm{C}$ with $5 \% \mathrm{CO}_{2}$ for $5-6$ days. The plates were fixed with $10 \%$ formalin for $30 \mathrm{~min}$ at room temperature and then stained with FITC conjugated anti-rabies monoclonal antibody (Fujirebio, Tokyo, Japan) at 1:10 dilution in $0.5 \% w / v$ bovine serum albumin (BSA)/phosphate buffered saline (PBSA) with $0.005 \%$ Evans blue. Plates were read with an Olympus BX51 inverted microscope (Olympus, Shinjuku City, Tokyo, Japan) and the median tissue culture infectious dose $\left(\mathrm{TCID}_{50}\right)$ determined [72]. The titer values of viral stocks used in this study were in the range of $10^{5-6} \mathrm{TCID}_{50} / \mathrm{mL}$. All experiments involving viruses were performed in the biosafety level 3 (BSL3) laboratories at Australian Animal Health Laboratory (AAHL), following protocols approved by AAHL's institutional biosafety committee.

\subsection{Viral Infection of Human ESC- and iPSC-Derived Neural Cultures}

For infection, hPSC-derived neural cultures in 24 well plates were treated with appropriate volumes of viral inoculum required to infect at virus: cell ratio of 1 (based on the viral titre determined in BHK-21 cells and the number of hNPCs seeded in each well prior to differentiation, i.e., $~ 40,000$ cells per well). For infecting hPSC-derived neural cultures in microfluidic chambers, media from the panel to be inoculated was removed and the appropriate volume of viral inoculum required to infect at a virus:cell ratio of 1 was added (based on the number of hNPCs seeded in the panel, i.e., 80,000 cells). A unidirectional flow of media was always maintained with a higher volume of media in the non-inoculated panel $(200 \mu \mathrm{L})$ and a lower volume in the inoculated panel $(100 \mu \mathrm{L})$.

\subsection{Generation of Trans-Synaptic Human Neural Cultures Using Microfluidics}

To generate an ex-vivo model of interconnected human neurons, xona microfluidic devices (XONA Microfluidics, Cat\#SND150, NC, USA) mounted on glass coverslips $(24 \times 40 \mathrm{~mm}$; Menzel Glaser, Braunschweig, Germany) coated with poly-L-ornithine (Sigma-Aldrich, St. Louis, MO, USA) were used. HDF51i-509-NPCs were seeded in both panels of a microfluidic device at a density of 80,000 cells per panel. After 2-3 days of further expansion in StemDiff NPM medium, differentiation was initiated by changing the media in the wells with BrainPhys ${ }^{\mathrm{TM}}$ complete neural differentiation media as described earlier. The hNPCs were then allowed to differentiate for 3-4 weeks with media change in the wells every 2 days. After differentiation and infection experiments, neural cultures were fixed in the chamber with $4 \% w / v$ paraformaldehyde (PFA, Sigma-Aldrich, St. Louis, MO, USA) in PBSA for $1 \mathrm{~h}$, followed by immunostaining and confocal imaging in the chamber.

\subsection{Immunocytochemistry}

Human stem cell-derived neural cultures cultured on coverslips were fixed with $4 \% w / v$ PFA (Sigma-Aldrich, St. Louis, MO, USA) in PBSA for $1 \mathrm{~h}$ at room temperature. The coverslips were washed gently three times with PBSA and the cells were permeabilized with $0.1 \% v / v$ Triton X-100 (Sigma-Aldrich, St. Louis, MO, USA) in PBSA for 5 min, rinsed with PBSA, then blocked with $0.5 \%$ $w / v$ BSA in PBSA for 30 min and incubated overnight at $4{ }^{\circ} \mathrm{C}$ with primary antibodies diluted in $0.5 \% w / v$ BSA in PBSA. They were washed three times with PBSA and incubated with species-specific fluorescent secondary antibodies (Alexa Fluor, Thermofisher Scientific, Waltham, MA, USA) diluted at $1: 200$ in $0.5 \%$ w $/ v$ BSA in PBSA for $1 \mathrm{~h}$ at room temperature. Coverslips were rinsed twice with PBSA, twice with sterile water, and stained with 4',6-diamidino-2-phenylindole (DAPI) for $10 \mathrm{~min}$, then were washed twice with sterile water and mounted on glass slides (Thermofisher Scientific Waltham, MA, USA) with Vectashield mounting medium (Vector Laboratories, Burlingame, CA, USA). 
The following primary antibodies were used at the indicated dilutions: chicken anti-MAP2 (1:1000, ABCAM, Cambridge, UK, cat\#ab4674), rabbit anti-GFAP (1:1000, DAKO, Berlin, Germany cat\#Z0334), mouse anti-beta tubulin III/TUJ1 (1:1000, ABCAM, Cambridge, UK, cat\#ab78078), rabbit anti-rabies nucleoprotein, 1:3000, in-house [73], mouse pan-axonal neurofilament antibody (1:1000, BioLegend, San Diego, CA, USA, cat\#837904), and mouse anti-NeuN (1:100, Merck, Kenilworth, NJ, USA, Cat\#MAB377).

\subsection{Apoptosis (TUNEL) Assay}

To quantify apoptosis in human stem cell-derived neural cultures infected with rabies virus, terminal deoxynucleotidyl transferase dUTP nick end labeling (TUNEL) staining was performed according to manufacturer's protocol using the in-situ cell death detection kit, TMR red (Sigma-Aldrich, St. Louis, MO, USA, cat\#12 156792 910). As a positive control for DNA fragmentation, fixed and permeabilized neuronal cultures on coverslips were treated with 3 units of DNaseI (Thermofisher Scientific, Waltham, MA, USA) in $50 \mathrm{mM}$ Tris-HCL for $15 \mathrm{~min}$ to induce DNA strand breaks. The cells were then stained with pan-axonal neurofilament antibody to identify neurons. Confocal images of neurons stained with TUNEL TMR red, neurofilament and DAPI were taken with 20× objective covering at least 100 neurons per image. The percentage of TUNEL-positive apoptotic bodies in these images (threshold normalized to controls), relative to DAPI stained nuclei were counted using imageJ (NIH, LOCI, University of Wisconsin, Madison, WI, USA) particle analyzer plugin and watershed function, with the following parameters: size $\left(\right.$ inch $\left.^{2}\right)-0.003$-infinity and circularity $-0.00-1.00$.

\subsection{Confocal Imaging}

Confocal imaging was performed using a ZEISS LSM 800 (ZEISS, Oberkochen, BW, Germany) inverted confocal microscope. Images were taken as Z-stacks and then maximum intensity projection was generated. For imaging neuronal network in microfluidic devices, a tile imaging was performed covering an area of $2.04 \mathrm{~mm} \times 892.84 \mu \mathrm{m}$ with Z-stacks (39 slices; $39.9 \mu \mathrm{m}$ ) and then stitched together for maximum intensity projection. All the confocal imaging and processing were performed using ZEN 2.5 Blue software (ZEISS, Oberkochen, BW, Germany).

\subsection{RNA Extraction and $c D N A$ Generation}

Total RNA from human stem cell-derived neural cultures infected with rabies virus strains were extracted using miRCURY RNA Isolation Kit-Cell and Plant (Exiqon, Copenhagen, Denmark) following manufacturer's protocol. RNA concentration was measured using a Nanodrop ND-1000 spectrophotometer (Thermofisher Scientific, Waltham, MA, USA) and the purity was confirmed by an absorbance ratio A260/A280 of 2.0-2.1. cDNA was synthesized from RNA using SuperScirpt ${ }^{\mathrm{TM}}$ III First-Strand synthesis system (Thermofisher Scientific, Waltham, MA, USA) following manufacturer's protocol. Random hexamers provided with the kit was used for non-specific reverse transcription of all RNA species.

\subsection{1. qPCR for Chemokine and Cytokine Gene Expression Analysis}

qPCR analysis was performed for chemokine and cytokine genes using a 96-well panel of primers for use with SYBR Green (BIO-RAD, Hercules, CA, USA, cytokines and chemokines, SAB target list, Human). qPCR analysis was performed using this panel of primers for a total of 91 human chemokines and cytokines following manufacturer's protocol using an ABI QuantStudio ${ }^{\mathrm{TM}} 6$ Flex Real-Time PCR instrument (Applied Biosystems, Foster city, CA, USA), in a 96-well FAST reaction, with the threshold for all reactions set to 0.1 . Cycling conditions were as follows: $95^{\circ} \mathrm{C}$ for $20 \mathrm{~s}$ followed by 40 cycles of 95 ${ }^{\circ} \mathrm{C}$ for $0.01 \mathrm{~s}$ and $60^{\circ} \mathrm{C}$ for $20 \mathrm{~s}$. A selection of 29 genes was identified to be differentially expressed in the initial screen on ESC-derived neural cultures infected with CVS-11 rabies virus. Then, a customized 96-well panel of primers was designed (BIO-RAD, Hercules, CA, USA) for the 29 genes, which was then used to perform qPCR analysis on both ESC- and iPSC-derived neural cultures infected with two rabies 
virus strains (CVS-11 and Z.Dog). Each reaction contained $10 \mathrm{ng}$ cDNA. Results were normalized to $\beta$-actin expression (included in the same reaction) and then converted to relative abundance via the fold-over-detectable method [74] using a Ct value of 40 as the detectability cut-off. Any undetectable results are reported with $\mathrm{Ct}$ of 40 .

\subsection{2. qPCR for Apoptosis and Necrosis Markers}

RNA was isolated and reverse transcribed using TRizol and SuperScirpt ${ }^{\mathrm{TM}}$ III reagents (Thermofisher Scientific, Waltham, MA, USA) following manufacturer's instructions using random hexamers. cDNA amplification was performed using a Quantstudio $^{\mathrm{TM}} 6$ Flex Real-time PCR system (Applied Biosystems, Foster city, CA, USA), in a 384-well standard reaction, with threshold for all reactions was set to 0.1. Cycling conditions were as follows: $50{ }^{\circ} \mathrm{C}$ for $2 \mathrm{~min}, 95{ }^{\circ} \mathrm{C}$ for $10 \mathrm{~min}$, followed by 40 cycles of $95{ }^{\circ} \mathrm{C}$ for $15 \mathrm{~s}$ and $60{ }^{\circ} \mathrm{C}$ for $1 \mathrm{~min}$. Each reaction contained $20 \mathrm{ng}$ cDNA. Samples were normalized to GAPDH for samples from H9-NPCs-derived neural cultures, ACTB for samples from HDF51i-509-NPC-derived neural cultures and expression levels calculated using the fold-over-detectable method [74]. Real-time primers included ACTB-F ACCATGGATGATGATATCGC, ACTB-R TCATTGTAGAAGGTGTGGTG, GAPDH-F AATGAAGGGGTCATTGATGG, GAPDH-R AAG GTGAAGGTCGGAGTCAA, MAP2-F CCACCTGAGATTAAGGATCA, MAP2-R GGCTTACTTTGCTTCTCTGA, GFAP-F GTACCAGGACC TGCTCAAT, GFAP-R CAACTATCCTGCTTCTGCTC, RIP1-F CATGGAAAAGGCGTGATACAC, RIP1-R ACTTCCCTCAGCTCATTGTG, caspase9-F TGCTGAGCAGCGAGCTGTT, caspase9-R AGC CTGCCCGCTGGAT.

\subsection{3. qPCR Assays for Detection of Lyssavirus}

Lyssavirus nucleoprotein RNA and 18S ribosomal (r)RNA were measured using AgPath-ID One-Step RT-PCR kit (Applied Biosystems, Foster city, CA, USA) as per the manufacturer's instructions, with a total RNA input of $30 \mathrm{ng}$. RABVD1 primers and FAM probe [75] were used detect CVS-11, SHBRV and Z.Dog strains, while the insectivorous ABLV primers and FAM probe [76] were used to detect H.ABLV. Both RABVD1 and ABLV primers were synthesized by Integrated DNA Technologies. Eukaryotic 18S rRNA Endogenous Control (VIC ${ }^{\text {TM }}$ / MGB probe, primer limited) primer/probe mix (Applied Biosystems, Foster city, CA, USA) was used for the detection of 18S rRNA. Quantitative PCR was conducted on the QuantStudio ${ }^{\mathrm{TM}} 6$ Flex Real-Time PCR instrument (Applied Biosystems, Foster city, CA, USA) using the standard reaction. Cycling conditions were as follows: $50^{\circ} \mathrm{C}$ for $2 \mathrm{~min}, 95^{\circ} \mathrm{C}$ for $10 \mathrm{~min}$, followed by 40 cycles of $95^{\circ} \mathrm{C}$ for $15 \mathrm{~s}$ and $60^{\circ} \mathrm{C}$ for $1 \mathrm{~min}$. The threshold for all reactions was set to 0.1. Lyssavirus nucleoprotein RNA levels were normalized to $18 \mathrm{~S}$ rRNA. Any undetectable results are reported with $\mathrm{Ct}$ of 40 .

\subsection{Statistical Analysis}

Changes in cytokine and chemokine expression were tested using the non-parametric Kruskal-Wallis $\mathrm{H}$ test. Any mRNA that rejected the null hypothesis $(p<0.05)$ was subjected to a post-hoc Dunn's Multiple Comparison Test with Benjamini-Krieger-Yekutieli two-stage false discovery rate correction [77]. These comparisons were completed using the SciPy [78] and scikit-posthocs [79] Python packages. Statistical significance between two values was determined using a two-tailed $t$ test using Prism 7 (GraphPad, San Diego, CA, USA).

Data are presented as mean \pm SEM. ${ }^{*} p<0.05,{ }^{* *} p<0.01,{ }^{* * *} p<0.0001 . n=3$, indicates three independent experiments. 


\section{Results}

\subsection{Generation and Characterization of Human ESC-and iPSC-Derived Neural Cultures}

In order to study rabies pathogenesis, we generated human neural cultures from the parental HDF51i-509-iPSC [58] and WA09(H9)-ESC [59] lines. Renewing neuronal precursor cell (hNPC) lines [60] were first established from each parental cell line. HNPCs were then further differentiated in-vitro, as described previously $[69,70]$, to establish mature forebrain-type neural cultures. These H9-NPC and HDF51i-509-NPC cultures were fixed following 21 and 24 days of differentiation respectively, for characterization by immunostaining and confocal microscopy. This demonstrated that both ESC- and iPSC-derived neural cultures consisted of mature neurons which positively stained for MAP2, TUJI (beta tubulin III) and NEUN, with GFAP-positive astrocytes (Figure 1a,d. To confirm efficient neural induction, we also performed gene expression analysis for neuronal (MAP2) and glial (GFAP) markers using qPCR (Figure 1b,e). This analysis showed greater expression of MAP2 and GFAP genes in differentiated neural cultures compared to the corresponding hNPC lines, demonstrating differentiation into neurons and astrocytes. To further evaluate the development of neuronal signaling mechanisms in these neural cultures, we performed calcium imaging with Fura-2 AM dye following 21 days and 26 days of differentiation of H9-NPC and HDF51i-509-NPC cultures, respectively. Calcium imaging demonstrated robust calcium influx in both these neural cultures in response to pharmacological stimulation with ATP and lower levels of calcium influx was recorded upon stimulation with dopamine or glutamate in some but not all neuronal cells imaged (Figure 1c,f, Supplementary Video S1). This suggests the presence of a mixed population of CNS resident neurons with varied excitability in response to stimulation with common neurotransmitters. In summary, these results demonstrate that both the $\mathrm{H} 9$ and HDF51i-509 derived neural cultures generated in this study consisted of mature and functional neurons with supporting astrocytes, representing a model neural culture system representative of human CNS resident cells.

\subsection{Lyssavirus Infection of Human Stem Cell-Derived Neural Cultures}

To examine the susceptibility of H9- and HDF51i-509-derived neural cultures to infection with different lyssavirus strains, cells were infected with laboratory-adapted CVS-11 strain, an Australian bat lyssavirus strain isolated from an infected horse (H.ABLV), a Canadian silver-head bat rabies virus (SHBRV), and a rabies virus strain isolated from an infected dog in Zimbabwe (Z.Dog). The neural cultures were infected with viral strains at a virus:cell ratio of 1 and examined for infectivity at $72 \mathrm{~h}$ post-infection. Immunostaining analysis demonstrated effective infection of both H9- and HDF51i-509-derived neural cultures with all the lyssavirus strains (Figure 2a,b). This resulted in the detection of rabies nucleoprotein antigen in the cell body as well as neurites of MAP2-positive neurons. However, no cytopathic effect was observed in the neural cultures infected with all the lyssavirus strains. In addition, qPCR analysis was performed using specific primers for the amplification and detection of nucleoprotein RNA from each of the rabies virus strains. Such an analysis detected high level of lyssavirus RNA in these neural cultures, indicating efficient infection (Figure 2c,d). 


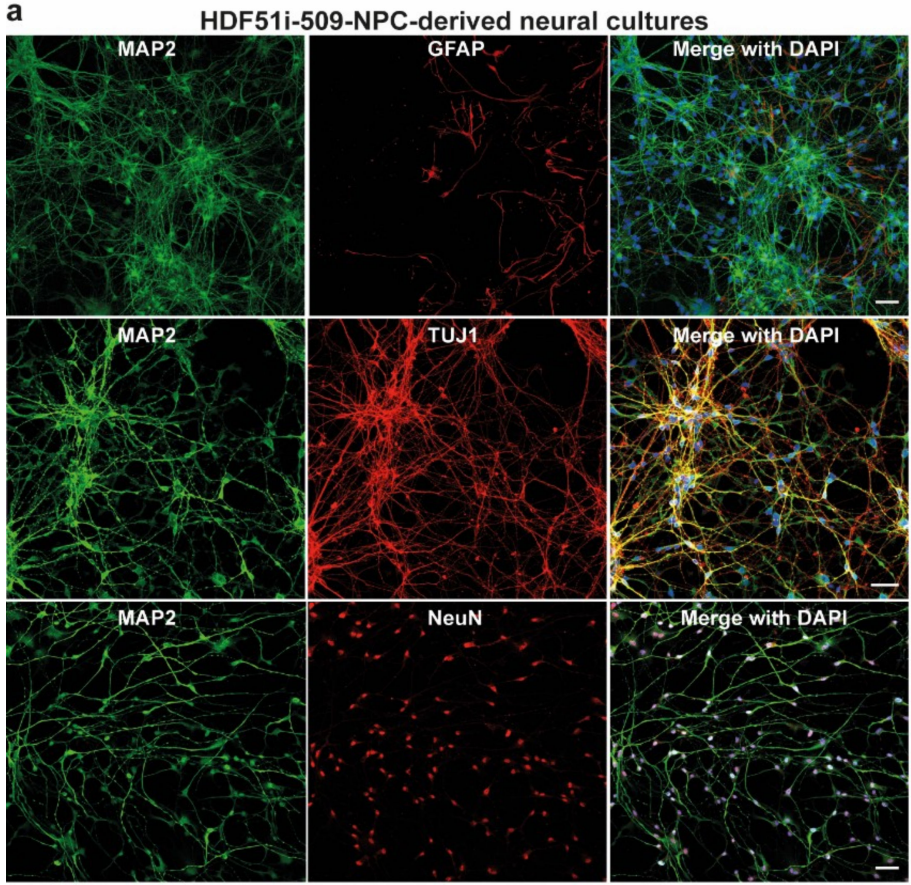

d

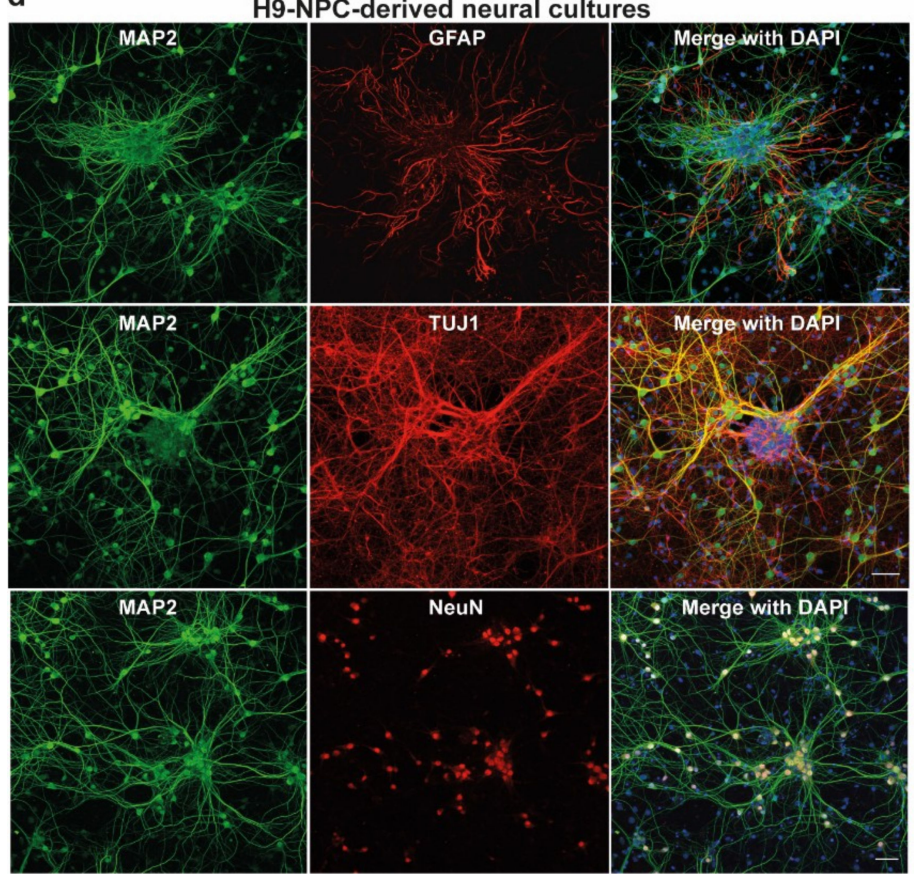

b
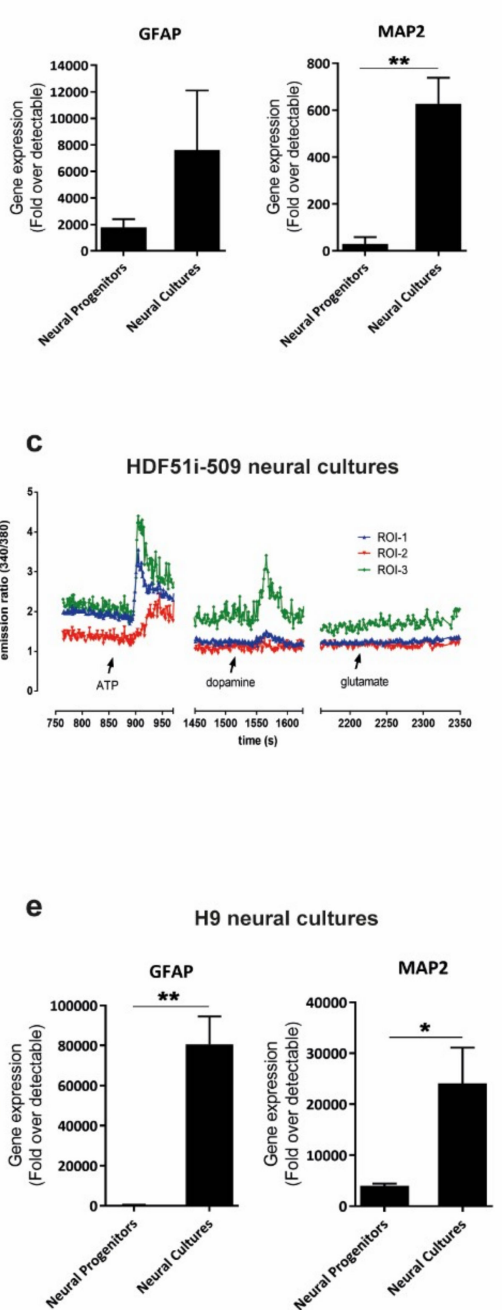

H9 neural cultures

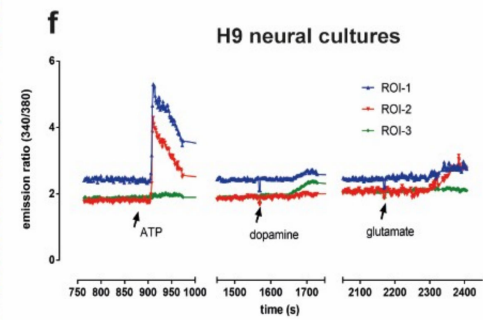

Figure 1. Generation of forebrain type human neural lineage cell cultures from induced pluripotent stem cells (iPSC)- and embryonic stem cells (ESC)-derived neuronal precursor cells (hNPCs). (a) HDF51i-509-derived and (d) H9-derived hNPCs were differentiated into forebrain type human neural cell cultures for 24 days and 21 days, respectively. The cultures were then immunostained for the detection of mature neuron markers MAP2, beta tubulin III (TUJI), and NeuN, as well as astrocytes using anti-GFAP antibody. Images were taken using $20 \times$ objective. Scale bar $50 \mu \mathrm{m}$ (images are maximum intensity projection of Z-stacks). Gene expression of neuronal (MAP2) and glial (GFAP), markers detected by qPCR in (b) HDF51i-509-derived and (e) H9-derived cultures following differentiation. ${ }^{* *} p<0.01,{ }^{*} p<0.05$ neural progenitors vs neural cultures, $n=3$. (c) HDF51i-509-NPC and (f) H9-NPC- 
derived neural cultures were subjected to live calcium imaging following loading with the calcium binding dye, Fura-2 AM. Cells morphologically characteristic of neurons with axonal projections are identified as regions of interest (ROI) for Fura-2 intensity measurements. Graphs (c,f) show representative calcium influx (measured by ratio of emission intensities at 340 and $380 \mathrm{~nm}$ ) in three different ROI in response to treatment with $100 \mu \mathrm{M}$ ATP, $100 \mu \mathrm{M}$ glutamate and $100 \mu \mathrm{M}$ dopamine. Arrows indicate the timepoint at which stimulants were added.

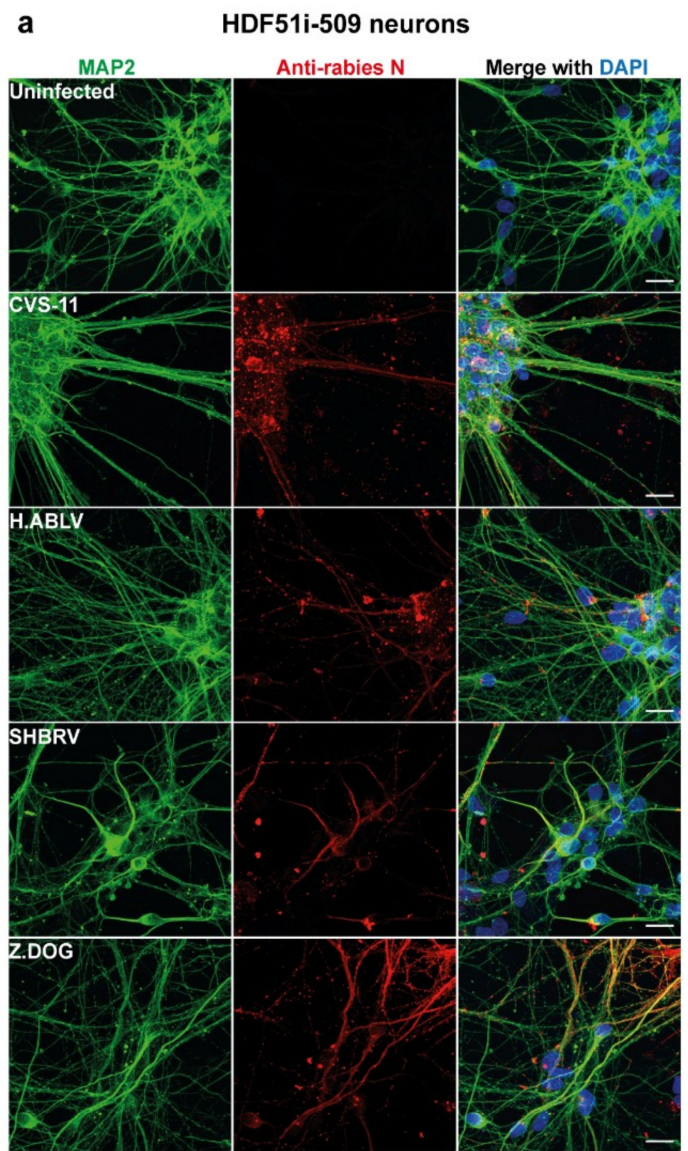

H9 neurons

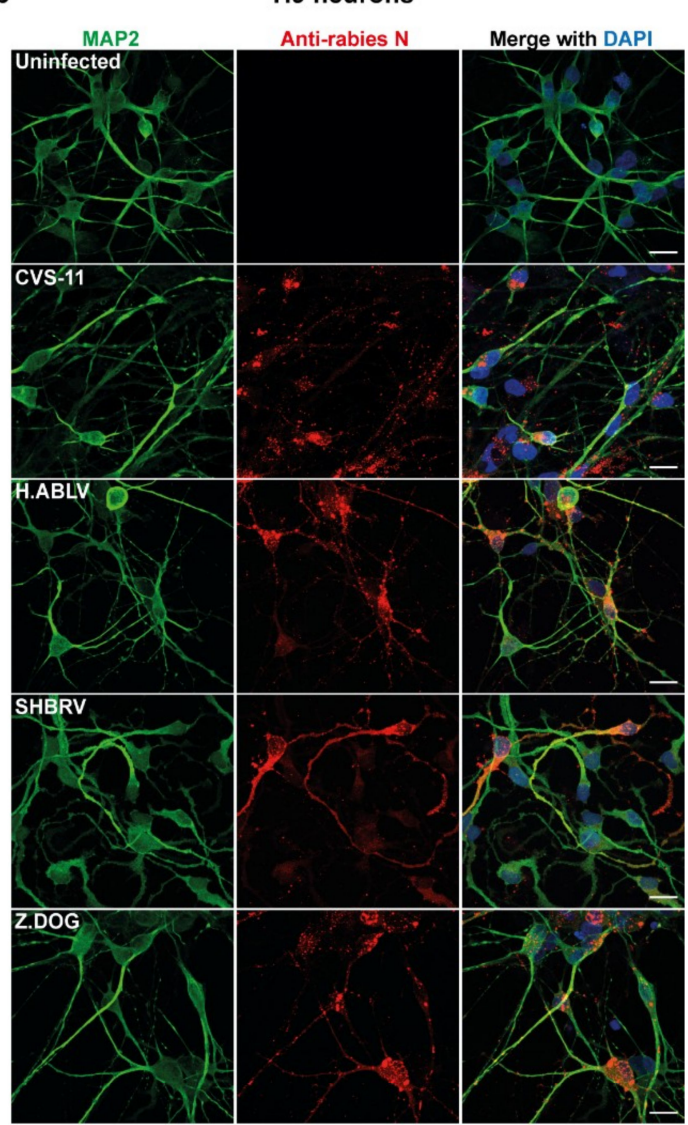

C

HDF51i-509 neural cultures

d
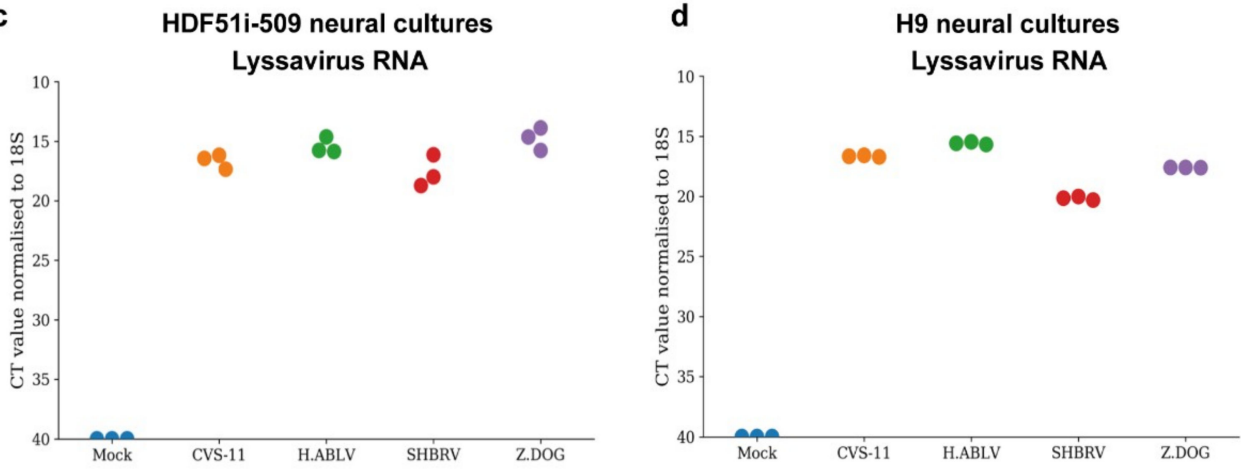

Figure 2. Lyssavirus infection of stem cell-derived human neural cultures. (a) HDF51i-509-NPCs and (b) H9-NPCs were differentiated for 21 days and 29 days, respectively. Differentiated neural cultures were then infected with different lyssavirus strains (CVS-11, H.ABLV, SHBRV and Z.DOG) at a virus:cell ratio of 1 for $72 \mathrm{~h}$. Representative images show infection of (a) HDF51i-509-NPC-derived and (b) H9-NPC-derived neural cultures immunostained for detection of MAP2-positive neurons (green) and rabies virus antigen by anti-nucleoprotein staining (red). Nuclei stained with DAPI (blue), shown as a merged image with red and green channels. Scale bar $50 \mu \mathrm{m}$ (images are maximum intensity projection of Z-stacks). (c,d) Validation of viral infection shown by qPCR analysis of lyssavirus RNA in (c) HDF51i-509-NPC- and (d) H9-NPC-derived neural cultures, $n=3$. 


\subsection{Lack of Apoptosis in Human Stem Cell-Derived Neural Cultures Infected with Lyssavirus}

Since human stem cell-derived neural cultures were highly susceptible to lyssavirus infection, we next examined whether such an infection could result in the induction of DNA fragmentation, indicative of neuronal apoptosis by TUNEL staining. DNA fragmentation was specifically examined in neurons identified by pan-axonal neurofilament antibody (Figure 3a), excluding the analysis of glial cells present in these neural cultures. This analysis revealed that none of the lyssavirus strain infection induced any significant increase in neuronal DNA fragmentation as compared to uninfected neural cultures derived from both H9 (Figure 3b) and HDF51i-509 (Figure 3c). However, a significantly higher percentage of TUNEL positive neurons were observed upon treatment with DNaseI enzyme, which induces DNA fragmentation reminiscent of apoptosis (Figure 3b,c). In addition, qPCR analysis was performed on the total RNA extracted from the lyssavirus infected neural cultures using specific primers for apoptotic and necrosis markers (Figure 3d,e). Such an analysis included RNA from both neuronal and glial cells in these cultures. This revealed negligible transcriptional activation of key genes involved in apoptosis (caspase9) or necrosis (RIP1) [80] in infected compared to non-infected neural cultures. This shows that lyssavirus infection does not induce apoptosis and cell death in human neural cultures containing both neuronal and glial cell types. 
a

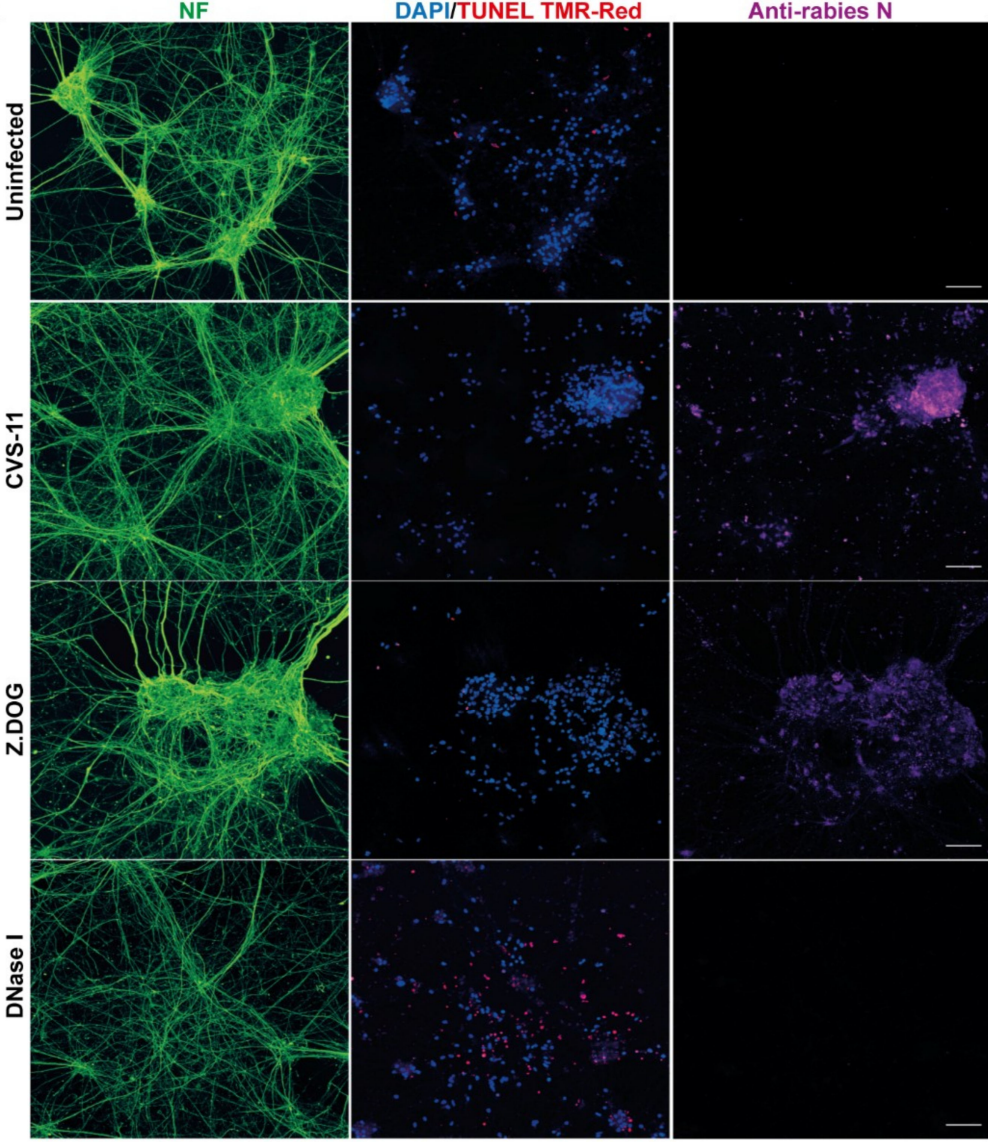

b

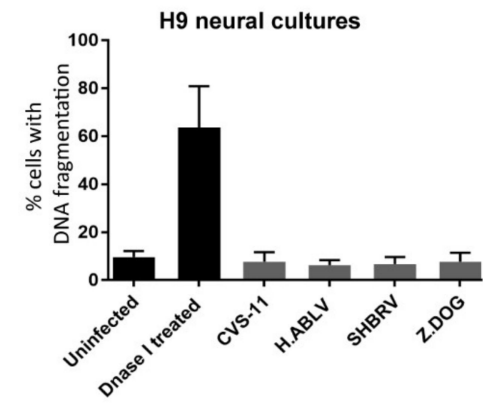

d

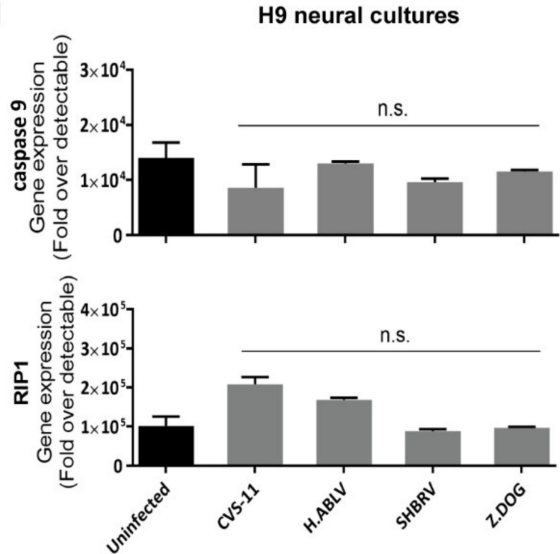

C

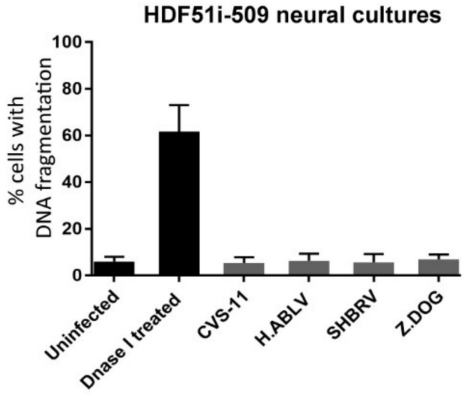

e
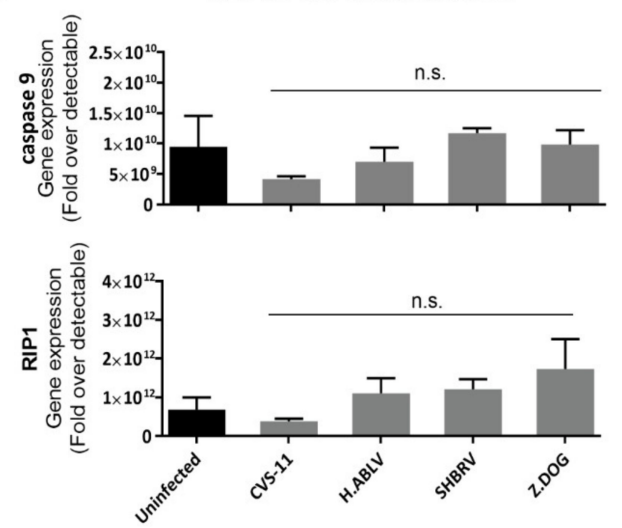

Figure 3. Lack of apoptosis in stem cell-derived human neural cultures infected with lyssavirus strains. HDF51i-509-NPCs and H9-NPCs were differentiated for 24 days and 29 days, respectively. These neural cultures were infected with different lyssavirus strains for $72 \mathrm{~h}$ at virus:cell ratio of 1 and examined for 
apoptosis by TUNEL staining (TMR-red). (a) Representatives images of HDF51i-509-NPC-derived neurons identified by anti-neurofilament immunofluorescence (NF, green) stained with TUNEL (red) and DAPI (blue) for nuclei. Infection with each lyssavirus strain was identified by anti-nucleoprotein staining (magenta). Images were taken with $20 \times$ objective and are maximum intensity projections of Z-stacks. Scale bar $50 \mu \mathrm{m}$. Quantification of apoptotic DNA fragmentation using TUNEL staining in (b) H9-NPC-derived neurons and (c) HDF51i-509-NPC-derived neurons. At least 500 neurons were quantified per sample, $n=3$. No statistical significance in apoptotic cell death observed between uninfected and lyssavirus infected neurons. qPCR analysis of apoptotic (caspase9) and necrosis (RIP1) genes in total RNA from (d) H9-NPC-derived and (e) HDF51i-509-NPC-derived neural cell cultures. No statistical significance difference is observed in the expression of caspase9 and RIP1 genes in uninfected and lyssavirus infected neural cultures.

\subsection{Upregulation of Distinct Pro-Inflammatory Chemokine and Cytokines in Human Stem Cell-Derived Neural} Cultures during Infection with Rabies Virus

We next examined whether rabies infection of human stem cell-derived neural cultures with rabies virus could trigger an immune response despite the lack of neuronal apoptosis. In this study, we first analyzed the gene expression profiles of a comprehensive list of chemokines and cytokines (Supplementary Table S1) in H9-NPC-derived neural cultures infected with CVS-11 and Z.Dog strains of rabies virus. In this initial analysis, we shortlisted 29 differentially expressed cytokine and chemokine genes (Supplementary Table S1), for which a custom array of primers was designed for further qPCR analysis. These gene expression profiles were then screened in neural cultures derived from both H9-NPCs and HDF51i-509-NPCs, infected with CVS-11 (Figure 4a) and Z.Dog (Figure 4b) rabies virus. Gene expression profiles of chemokines and cytokines were quantified by the relative fold change compared to mock-infected neural cultures treated with PBS (Figure 4a,b) and their relative transcript abundance (Figure $4 \mathrm{c}-\mathrm{e}$ ). In this analysis, the highest upregulation was observed for CCL5/RANTES and CSF1 in both CVS-11 (Figure 4a) and Z.Dog rabies infection (Figure 4b), compared with mock infection. Other proinflammatory genes which were significantly upregulated in both the rabies virus strains include IL15, IL17F, CCL1, CXCL13, and CXCL1 (Figure 4c). In addition, IL5 and TNFSF13B/BAFF were found to be significantly upregulated in CVS-11 infection but not with the Z.Dog strain (Figure 4d). CCL17 and CCL5 mRNA were both upregulated at significantly higher level in CVS-11 infection compared to Z.Dog infection (Figure 4e). Interestingly, while we did not observe a significant upregulation of type I interferon gene (IFNA2) in neither CVS-11 nor Z.Dog infection, we observed specific upregulation of type II interferon gene (IFN- $\gamma$ ) in Z.Dog infection (Figure 4e). The expression of this IFN- $\gamma$ gene was undetectable in the mock infected or CVS-11 infected neural cultures (Figure 4e). These results show a robust but strain specific immune response in both H9-NPCand HDF51i-509-NPC-derived neural cultures in response to rabies infection. 
A

CVS-11

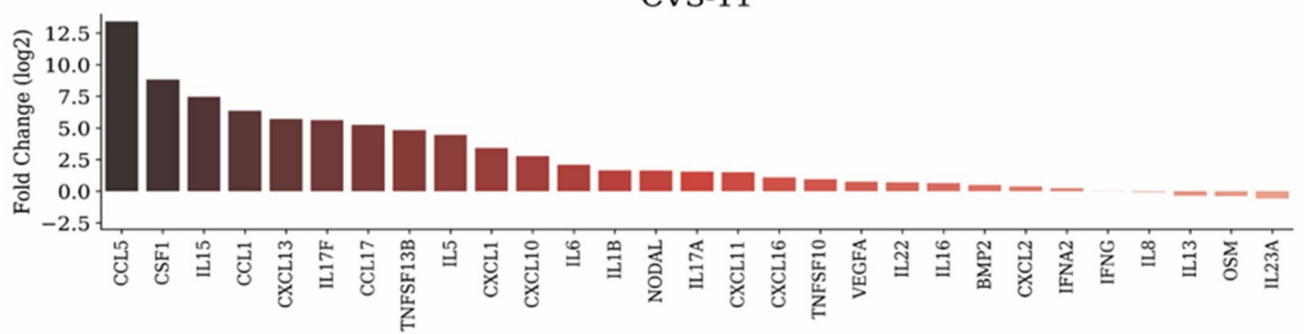

B

Z.DOG
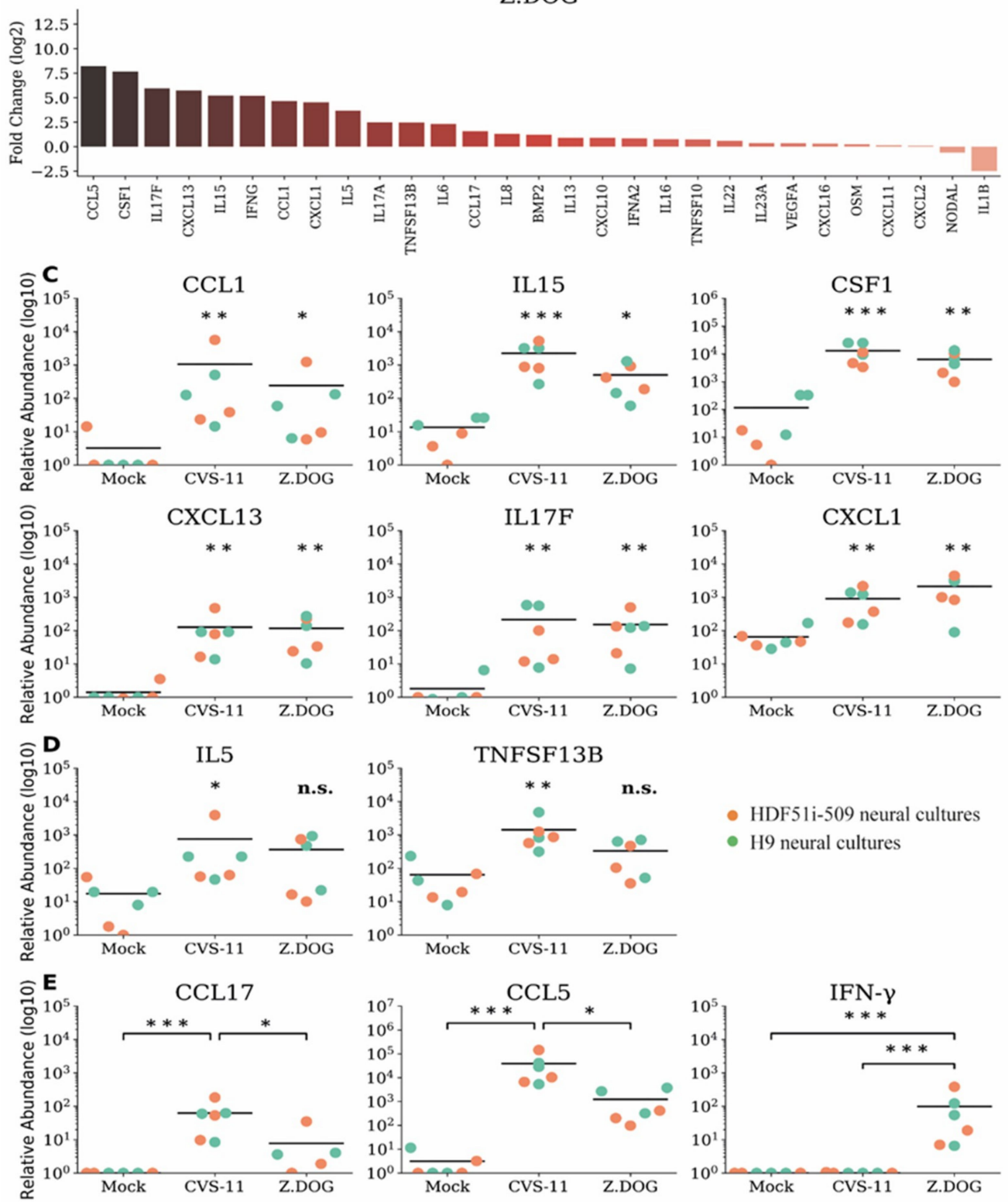

- HDF51i-509 neural cultures

- H9 neural cultures
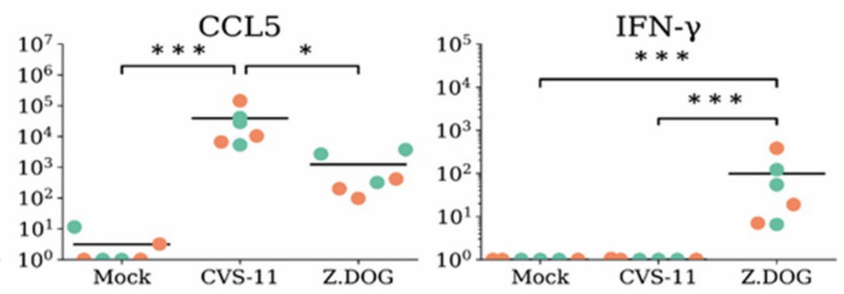

Figure 4. Gene expression profiles of chemokines and cytokines in H9- and HDF51i-509-derived human neural cultures infected with CVS-11 and Z.Dog rabies virus. H9-NPCs and HDF51i-509-NPCs were differentiated for 27 days and 28 days, respectively, before infection with rabies virus. qPCR analysis of chemokine and cytokine genes (29 genes selected from initial screen of 91 genes, Supplementary Materials Table S1) in H9-NPC and HDF51i-509-NPC-derived neural cultures infected with CVS-11 and Z.Dog rabies virus for $72 \mathrm{~h}$ at virus:cell ratio of 1 . (a,b) Graphs show fold change (log2) of all 29 genes screened relative to mock infection in both H9-NPC-derived and HDF51i-509-NPC-derived neural cultures. (a) Infection with CVS-11 and (b) infection with Z.Dog strain. (c) Graphs show group 
cytokines found to be significantly upregulated $(p<0.05)$ in both CVS-11 and Z.Dog infection, when compared with mock infection. (d) Graphs show IL5 and TNFSF13B/BAFF gene expression levels which were found to significantly regulated in CVS-11 infection but not with Z.Dog. (e) Graphs show group of cytokines including IFN- $\gamma$ found to differently upregulated in Z.Dog infection in comparison to CVS-11 infection. ${ }^{*} p<0.05,{ }^{* *} p<0.01,{ }^{* * *} p<0.001$, n.s. $=$ not significant. $n=3$. Mean values are indicated by horizontal lines in the graph.

3.5. Stem Cell-Derived Ex-Vivo Models of Human Neuronal Network Reveals Differential Dynamics in the Axonal Transmission of Rabies Virus Strains

Axonal transmission of rabies virus between trans-synaptically connected neurons in the host nervous system is an important feature of rabies pathogenesis. However, this mechanism has not been studied in human neurons. In this study, we used a microfluidic chamber to generate a human ex-vivo neuronal model system for studying axonal transmission of rabies virus between interconnected neurons. Here, we seeded hNPCs derived from HDF51i-509 in the adjoining panels of a microfluidic device separated by microchannels which prevents the passage of cell bodies (Figure 5a). When these hNPCs were differentiated as previously described, the developing axonal structures passed through the microchannels, connecting the neuronal cultures on adjacent panels. After 26 days of hNPC differentiation, the neural cultures were infected with CVS-11 rabies virus on the inoculated panel and fixed after $72 \mathrm{~h}$ of infection in the microfluidic device. In such infections, a higher volume of media is maintained in the non-inoculated panel to maintain unidirectional flow of culture media and avoid random diffusion of viral inoculum from the inoculated panel, except via axonal transmission. Immunostaining and confocal microscopy analysis of these neural cultures displayed extensive detection of MAP2-postive neuronal networks between the panels (Figure 5b). Immunostaining with rabies nucleoprotein antibody also revealed efficient axonal transmission of rabies virus from the infected neurons in one panel to the uninfected neurons in the other panel after $72 \mathrm{~h}$ of infection (Figure 5b,c). We further investigated any difference in axonal transmission between the CVS-11 and Z.Dog strains in this model system. HDF51i-509-NPCs were similarly differentiated in microfluidic chambers and inoculated with either CVS-11 or Z.Dog strains. Following $24 \mathrm{~h}$ inoculation, the cultures were fixed and analyzed by immunostaining. This analysis identified extensive infection with CVS-11 rabies virus strain in the inoculated panel as well as in the non-inoculated panel, suggesting axonal transmission of the virus extensively within the neuronal network within $24 \mathrm{~h}$ of infection (Figure 5d). Whilst the Z.Dog strain was able to infect the MAP2-positive neurons in the inoculated panel, the spread of infection to neurons in the non-inoculated panel was significantly reduced compared to CVS-11 (Figure 5d,e). These results suggest that there may be strain specific differences in the dynamics of viral replication and axonal transmission of rabies virus in human neuronal network. 
a HDF51i-509-NPC in microfluidic chamber

b

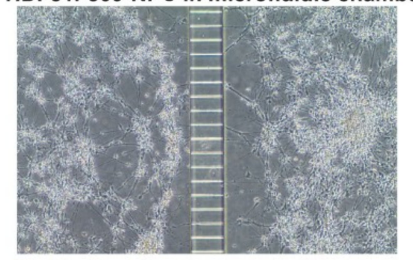

HDF51i-509-IPSC neurons in microfluidic chamber

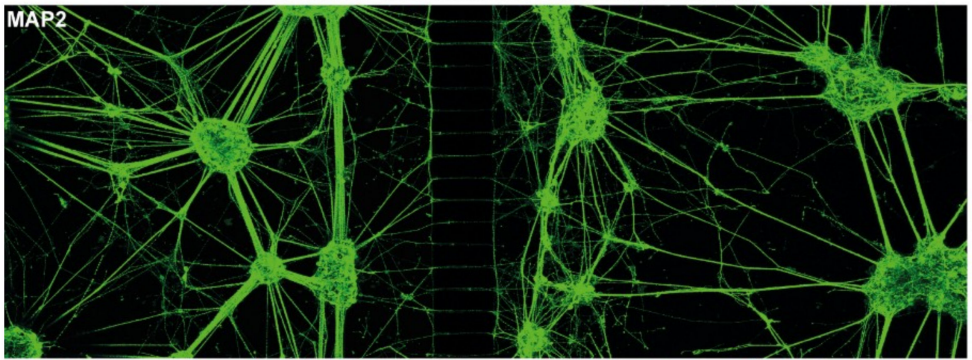

Anti-rabies $\mathbf{N}$

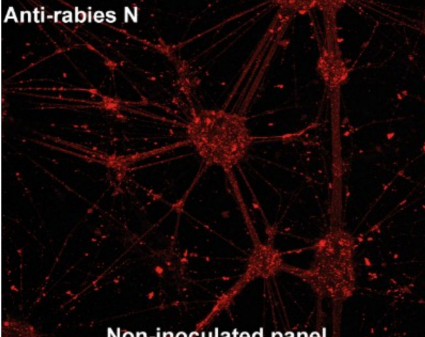

Non-inoculated panel

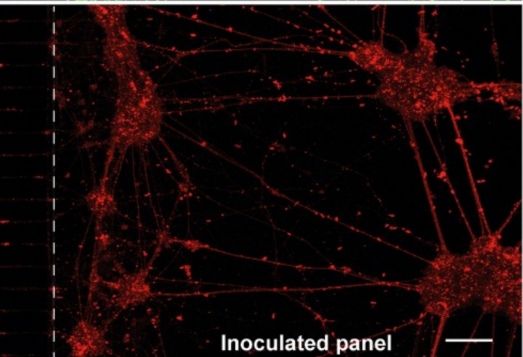

c

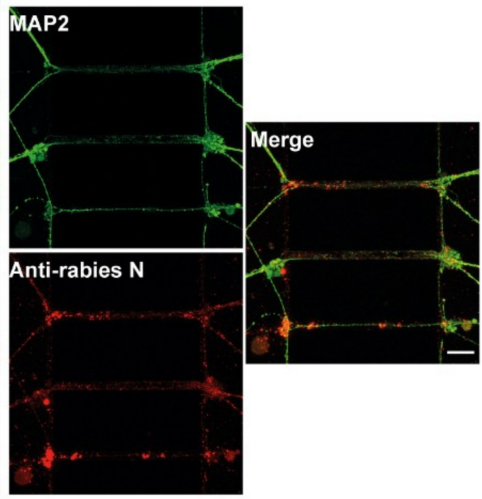

d

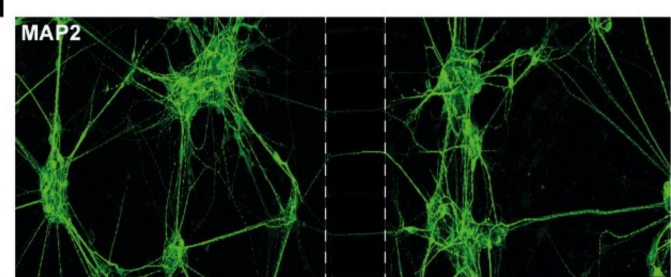

MAP2

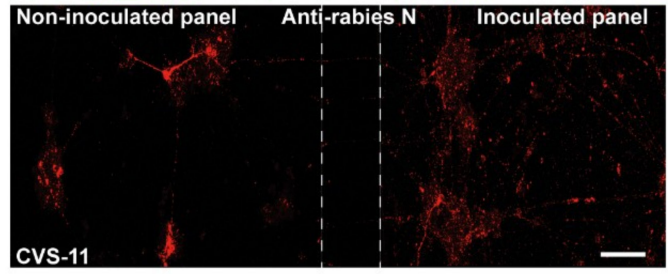

Non-inoculated pan

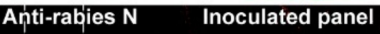

e

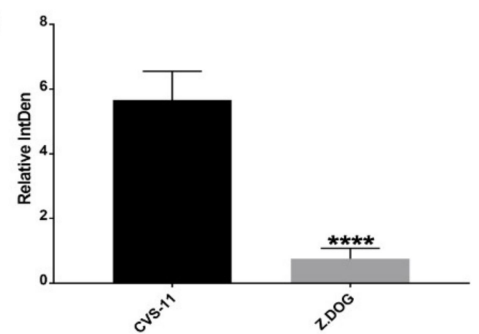

Figure 5. Stem cell-derived ex-vivo model of human neuronal network. (a) Representative DIC image taken using 10× objective of Xona microfluidic device seeded with HDF51i-509-NPCs at 5 days post-differentiation. (b) HDF51i-509-NPCs after 26 days of differentiation in microfluidic device were infected with CVS-11 rabies virus in the inoculated panel for $72 \mathrm{~h}$. A unidirectional flow of media from the non-inoculated panel to the inoculated panel is maintained to prevent random diffusion of viral particles. Immunostaining with MAP2 (green) reveals extensive neuronal network between the panels after 26 days of differentiation. Immunostaining with rabies nucleoprotein antibody (red) shows equivalent viral antigen between both panels, indicating efficient spread of CVS-11 rabies infection within and between the neuronal networks of both panels. Confocal images were taken using 
$20 \times$ objective with tile function and stitched together. Scale bar $100 \mu \mathrm{m}$ (images are maximum intensity projection of Z-stacks) (c) Representative high magnification (40×) confocal images shown in (b). Scale bar $10 \mu \mathrm{m}$. Images show spread of rabies antigen (red) in MAP2-neurites (green) within microchannels. (d) HDF51i-509-NPC-derived neural cultures in microfluidic device after 26 days of differentiation were infected with CVS-11 or Z.Dog rabies virus for $24 \mathrm{~h}$. Confocal images show increased presence of rabies antigens (red) in the non-inoculated panel of CVS-11 infection when compared with Z.Dog infection. (e) Quantification of relative intensity of rabies nucleoprotein staining in the inoculated panel versus non-inoculated panel in CVS-11 and Z.Dog infection. Data show significantly reduced viral antigen staining in the non-inoculated panel of Z.Dog infection compared to CVS-11 infection. ${ }^{* * * *} p<0.0001$ Z.Dog versus CVS-11 infection, $n=3$.

\section{Discussion}

In this study, we demonstrate that human ESC- and iPSC-derived neural cultures could be used as effective ex-vivo models to study several pathogenic mechanisms associated with human rabies. We generated ESC- and iPSC-derived human neural cultures consisting of mature neurons identified by positive immunostaining for mature neuronal markers and development of calcium signaling mechanisms. We show that these ESC- and iPSC-derived neural cultures are highly susceptible to infection with different strains of lyssavirus. We then sought to perform a basic validation of whether this system could reproduce key features of rabies pathogenesis, which have been previously identified in classical in-vitro and in-vivo mouse model systems. Lyssavirus infection in human neural cultures did not led to the induction of apoptosis but resulted in a pro-inflammatory state as evidenced by upregulation of specific subsets of cytokine genes, consistent with the findings in mouse models $[23,25,26,30,81-83]$. In addition, we demonstrate the need to consider differences in the characteristics of viral strains when selecting ex-vivo models for human rabies. We show strain-specific difference in the cytokine upregulation and axonal transmission of rabies virus between interconnected axons in our novel system of synaptically connected human neurons. In summary, these results show that human stem cell-derived neural cultures could be used as effective models to study the cellular and molecular pathogenic mechanisms of human rabies, alongside classical animal models.

The evasion of host immune response is a key feature of rabies pathogenesis. The viral mechanisms behind immune evasion are yet to be investigated at a cellular level in human neural culture systems. Therefore, to validate whether our model could be suitable for this objective, we examined cytokines and chemokine response in stem cell-derived human neural cultures infected with rabies virus. Most of the cytokines identified to be upregulated in this study have demonstrated roles in mediating neuroinflammation by promoting infiltration and activation of immune cells into the CNS, activation of CNS resident inflammatory glial cells, and increased permeability of BBB. CCL5 was found to be the highest upregulated chemokine gene in human neural cultures in response to infection with both CVS-11 and Z.Dog rabies infection compared to uninfected cultures. CCL5 plays a key role in the disruption of BBB leading to the infiltration of inflammatory cells in the CNS and neuroinflammation in various pathological conditions [84-88]. Previous studies in mice have also identified CCL5 to be the highest upregulated chemokine in response to both attenuated and wildtype rabies virus infection in-vivo [25]. Additionally, inhibiting CCL5 signaling prolonged survival time of mice infected with rabies virus, by reducing the upregulation of proinflammatory cytokines in the CNS [25]. These findings, in addition to our data, suggest that CCL5 may be a target for therapeutic intervention in human rabies. However, CCL5 plays a role in controlling neurotransmission by modulating glutamate release at the synapses $[89,90]$ and dysregulation of CCL5 mediated glutamatergic transmission is linked with psychiatric disorders [89-92]. In addition, CCL5 also promotes neuronal survival during injury involving toxic insults $[93,94]$. Hence, a broader investigation of CCL5 in rabies pathogenesis is necessary to fully understand its role beyond classical proinflammatory signaling in the CNS and scrutiny needs to be exercised when considering a therapeutic option that may aggressively target 
these pathways. The implications of comparatively reduced upregulation of CCL5 in non-adapted Z.Dog rabies infection also needs to be studied in this model system.

CSF1 was found to be the second most upregulated chemokine in response to both CVS-11 and Z.Dog strain rabies infection in human neural cultures. CSF1 regulates microglial activation and proliferation [95] and also plays a role in local activation of infiltrating $\mathrm{T}$ cells aiding viral clearance from the brain [96]. In concert with CSF1 upregulation, other cytokines involved in microglial activation and proliferation, such as CCL1 [97] and IL15 [98], were found to be upregulated in both CVS-11 and Z.Dog strain infections. In addition, other microglia activating cytokines, such as IL5 [99] and CCL17 [100], were found to be significantly upregulated in CVS-11 infection. Cytokines relating to the activation of non-CNS resident immune cells were also found to be upregulated in this study, including CXCL13 (B cells) [101] and CXCL1 (neutrophils) [102]. B-cell activating factor (BAFF) encoded by the TNFSF13B gene, which mediates the proliferation of B cells in the CNS [103], was found to be significantly upregulated in CVS-11 infection. In contrast, we identified specific upregulation of type II interferon IFN- $\gamma$ in Z.Dog rabies virus infection, which was not detected in uninfected and CVS-11 rabies virus infected neural cultures. IFN- $\gamma$ activates a potent anti-viral response through STAT1 signalling $[104,105]$ and also functions in altering tight-junction proteins, leading to increased BBB permeability $[27,106]$. In summary, rabies infection in human neuronal cultures results in the upregulation of specific cytokines involved in neuroinflammation by activation of microglia and other infiltrating immune cells in the CNS. The mechanisms behind upregulation of these cytokines, downstream cascades, or potential viral inhibition of cytokine-induced responses were not examined in this study. None the less, the observation of specific cytokine response in this novel human stem cell-derived neuronal model systems following rabies infection, demonstrates that this culture system could serve as an effective tool for future investigation of host viral interactions.

In addition to specific cytokine response, the human stem cell-derived neural cultures developed in this study also demonstrated transsynaptic transmission of rabies virus, a key mechanism responsible for its spread throughout the nervous system [5]. Rabies virus interacts with neuronal membrane receptors and hijacks endosomal trafficking pathways in the axons to mediate anterograde transport in the nervous system $[10,35,107]$. The reverse genetics approach has enabled the identification of several viral elements responsible for neuroinvasion and axonal trafficking $[10,35,108]$. In this study, we have developed a stem cell-derived ex-vivo model of human neuronal network which enables the study of viral replication and axonal trafficking between human neuronal populations. We further demonstrate more efficient virus replication and axonal transmission in a laboratory-adapted CVS-11 strain compared to a non-adapted Z.Dog strain in this model, consistent with existing knowledge $[108,109]$. Therefore, this newly described infection model provides an enhanced capability to investigate molecular mechanisms of rabies axonal trafficking in human neurons, using techniques such as reverse genetics.

In summary, this study introduces a new ex-vivo model system for studying the key pathogenic features of rabies in human neurons. This ex-vivo model system provides exciting new opportunities in identifying novel cellular mechanisms associated with the pathogenesis of rabies and will compliment current in-vitro and in-vivo models for studying this devastating disease.

Supplementary Materials: The following are available online at http://www.mdpi.com/1999-4915/12/4/359/s1, Table S1: List of 91 genes initially screened by qPCR in total RNA extracted from H9-NPC-derived neural cultures infected with CVS-11 and Z.Dog strains. Table S1 highlights the genes selected for custom array qPCR assay with corresponding CT values. Video S1: Representative video from calcium imaging experiments. H9-NPCs were differentiated for 21 days and imaged with calcium-binding Fura-2 AM dye. Video S1 shows response of neural cultures upon stimulation with $100 \mu \mathrm{M}$ ATP.

Author Contributions: Conceptualization, C.M.O., M.D., J.B. and V.S.; Methodology, V.S., R.J.F., N.G., J.M.H., C.M.O.; Investigation, V.S., D.G., R.J.F., N.G. and J.M.H.; Formal analysis, V.S., R.J.F. and N.G.; Writing-Original Draft, V.S.; Writing—Review \& Editing, C.M.O., M.D., and J.B.; Visualization, V.S.; Supervision, M.D., C.M.O. and J.B.; Project administration, M.D. and J.B. All authors have read and agreed to the published version of the manuscript. 
Funding: This research received no specific external funding. Previous hPSC-NPC derivation research was supported by California Institute for Regenerative Medicine (CIRM) joint grant funding (TR3-05603) with Australia's NHMRC to C.M.O. [60].

Acknowledgments: We are grateful for the support of Pathology \& Pathogenesis, Small Animal Facility and Tissue Culture teams at AAHL. The Bioassays R\&D Team provided the anti-rabies nucleoprotein antibody used in this study. We thank Christine Fehlner-Gardiner, Centre of Expertise for Rabies, Canadian Food Inspection Agency and the Thailand Department of Livestock Development (DLD) and National Institute of Animal Health (NIAH) for providing rabies viral isolates. Microscopy Australia, through NCRIS funding, supported the confocal microscopy capability utilised in this study. We thank Andrew Laslett (CSIRO) for laboratory support of initial hNPC neural differentiation experiments.

Conflicts of Interest: The authors declare no conflict of interest.

\section{References}

1. Delmas, O.; Holmes, E.C.; Talbi, C.; Larrous, F.; Dacheux, L.; Bouchier, C.; Bourhy, H. Genomic diversity and evolution of the lyssaviruses. Plos One 2008, 3, e2057. [CrossRef] [PubMed]

2. Troupin, C.; Dacheux, L.; Tanguy, M.; Sabeta, C.; Blanc, H.; Bouchier, C.; Vignuzzi, M.; Duchene, S.; Holmes, E.C.; Bourhy, H. Large-scale phylogenomic analysis reveals the complex evolutionary history of rabies virus in multiple carnivore hosts. Plos Pathog. 2016, 12, e1006041. [CrossRef] [PubMed]

3. Shipley, R.; Wright, E.; Selden, D.; Wu, G.; Aegerter, J.; Fooks, A.R.; Banyard, A.C. Bats and viruses: Emergence of novel lyssaviruses and association of bats with viral zoonoses in the eu. Trop. Med. Infect. Dis. 2019, 4, 31. [CrossRef] [PubMed]

4. Rupprecht, C.; Kuzmin, I.; Meslin, F. Lyssaviruses and rabies: Current conundrums, concerns, contradictions and controversies. F1000Research 2017, 6, 184. [CrossRef] [PubMed]

5. Schnell, M.J.; McGettigan, J.P.; Wirblich, C.; Papaneri, A. The cell biology of rabies virus: Using stealth to reach the brain. Nat. Rev. Microbiol. 2010, 8, 51. [CrossRef] [PubMed]

6. Knobel, D.L.; Cleaveland, S.; Coleman, P.G.; Fèvre, E.M.; Meltzer, M.I.; Miranda, M.E.G.; Shaw, A.; Zinsstag, J.; Meslin, F.-X. Re-evaluating the burden of rabies in africa and asia. Bull. World Health Organ. 2005, 83, 360-368.

7. Hampson, K.; Coudeville, L.; Lembo, T.; Sambo, M.; Kieffer, A.; Attlan, M.; Barrat, J.; Blanton, J.D.; Briggs, D.J.; Cleaveland, S. Estimating the global burden of endemic canine rabies. Plos Negl. Trop. Dis. 2015, 9, e0003709.

8. Kessels, J.A.; Recuenco, S.; Navarro-Vela, A.M.; Deray, R.; Vigilato, M.; Ertl, H.; Durrheim, D.; Rees, H.; Nel, L.H.; Abela-Ridder, B. Pre-exposure rabies prophylaxis: A systematic review. Bull. World Health Organ. 2017, 95, 210. [CrossRef]

9. Dietzschold, B.; Schnell, M.; Koprowski, H. Pathogenesis of rabies. In The World of Rhabdoviruses; Springer: New York, NY, USA, 2005; pp. 45-56.

10. Gluska, S.; Zahavi, E.E.; Chein, M.; Gradus, T.; Bauer, A.; Finke, S.; Perlson, E. Rabies virus hijacks and accelerates the p75ntr retrograde axonal transport machinery. Plos Pathog. 2014, 10, e1004348. [CrossRef]

11. Hosking, M.P.; Lane, T.E. The role of chemokines during viral infection of the cns. Plos Pathog. 2010, 6, e1000937. [CrossRef]

12. Veiga-Fernandes, H.; Artis, D. Neuronal-immune system cross-talk in homeostasis. Science 2018, 359, 1465-1466. [CrossRef]

13. Arima, Y.; Kamimura, D.; Sabharwal, L.; Yamada, M.; Bando, H.; Ogura, H.; Atsumi, T.; Murakami, M. Regulation of immune cell infiltration into the cns by regional neural inputs explained by the gate theory. Mediat. Inflamm. 2013, 2013. [CrossRef] [PubMed]

14. Klein, R.S.; Lin, E.; Zhang, B.; Luster, A.D.; Tollett, J.; Samuel, M.A.; Engle, M.; Diamond, M.S. Neuronal cxcl10 directs cd8+ t-cell recruitment and control of west nile virus encephalitis. J. Virol. 2005, 79, 11457-11466. [CrossRef]

15. Aravalli, R.N.; Hu, S.; Rowen, T.N.; Palmquist, J.M.; Lokensgard, J.R. Cutting edge: Tlr2-mediated proinflammatory cytokine and chemokine production by microglial cells in response to herpes simplex virus. J. Immunol. 2005, 175, 4189-4193. [CrossRef]

16. Ransohoff, R.M.; Brown, M.A. Innate immunity in the central nervous system. J. Clin. Investig. 2012, 122, 1164-1171. [CrossRef] [PubMed] 
17. Becher, B.; Prat, A.; Antel, J.P. Brain-immune connection: Immuno-regulatory properties of cns-resident cells. Glia 2000, 29, 293-304. [CrossRef]

18. Lafon, M. Evasive strategies in rabies virus infection. In Advances in Virus Research; Elsevier: Amsterdam, The Netherlands, 2011; Volume 79, pp. 33-53.

19. Brzózka, K.; Finke, S.; Conzelmann, K.-K. Inhibition of interferon signaling by rabies virus phosphoprotein p: Activation-dependent binding of stat1 and stat2. J. Virol. 2006, 80, 2675-2683. [CrossRef]

20. Wiltzer, L.; Okada, K.; Yamaoka, S.; Larrous, F.; Kuusisto, H.V.; Sugiyama, M.; Blondel, D.; Bourhy, H.; Jans, D.A.; Ito, N. Interaction of rabies virus p-protein with stat proteins is critical to lethal rabies disease. J. Infect. Dis. 2013, 209, 1744-1753. [CrossRef]

21. Ito, N.; Moseley, G.W.; Blondel, D.; Shimizu, K.; Rowe, C.L.; Ito, Y.; Masatani, T.; Nakagawa, K.; Jans, D.A.; Sugiyama, M. Role of interferon antagonist activity of rabies virus phosphoprotein in viral pathogenicity. J. Virol. 2010, 84, 6699-6710. [CrossRef]

22. Fernandes, E.R.; de Andrade Jr, H.F.; Lancellotti, C.L.P.; Quaresma, J.A.S.; Demachki, S.; da Costa Vasconcelos, P.F.; Duarte, M.I.S. In situ apoptosis of adaptive immune cells and the cellular escape of rabies virus in cns from patients with human rabies transmitted by desmodus rotundus. Virus Res. 2011, 156, 121-126. [CrossRef]

23. Baloul, L.; Lafon, M. Apoptosis and rabies virus neuroinvasion. Biochimie 2003, 85, 777-788. [CrossRef]

24. Scott, T.P.; Nel, L.H. Subversion of the immune response by rabies virus. Viruses 2016, 8, 231. [CrossRef] [PubMed]

25. Huang, Y.; Jiao, S.; Tao, X.; Tang, Q.; Jiao, W.; Xiao, J.; Xu, X.; Zhang, Y.; Liang, G.; Wang, H. Met-ccl5 represents an immunotherapy strategy to ameliorate rabies virus infection. J. Neuroinflammation 2014, 11, 146. [CrossRef] [PubMed]

26. Johnson, N.; Mansfield, K.; Hicks, D.; Nunez, A.; Healy, D.; Brookes, S.; McKimmie, C.; Fazakerley, J.; Fooks, A. Inflammatory responses in the nervous system of mice infected with a street isolate of rabies virus. Dev. Biol. 2008, 131, 65-72.

27. Chai, Q.; He, W.Q.; Zhou, M.; Lu, H.; Fu, Z.F. Enhancement of blood-brain barrier permeability and reduction of tight junction protein expression are modulated by chemokines/cytokines induced by rabies virus infection. J. Virol. 2014, 88, 4698-4710. [CrossRef] [PubMed]

28. Chai, Q.; She, R.; Huang, Y.; Fu, Z.F. Expression of neuronal cxcl10 induced by rabies virus infection initiates infiltration of inflammatory cells, production of chemokines and cytokines, and enhancement of blood-brain barrier permeability. J. Virol. 2015, 89, 870-876. [CrossRef] [PubMed]

29. Jackson, A.C.; Randle, E.; Lawrance, G.; Rossiter, J.P. Neuronal apoptosis does not play an important role in human rabies encephalitis. J. Neurovirology 2008, 14, 368-375. [CrossRef] [PubMed]

30. Suja, M.; Mahadevan, A.; Madhusudana, S.; Shankar, S. Role of apoptosis in rabies viral encephalitis: A comparative study in mice, canine, and human brain with a review of literature. Pathol. Res. Int. 2011, 2011. [CrossRef]

31. Préhaud, C.; Lay, S.; Dietzschold, B.; Lafon, M. Glycoprotein of nonpathogenic rabies viruses is a key determinant of human cell apoptosis. J. Virol. 2003, 77, 10537-10547. [CrossRef]

32. Hemachudha, T.; Ugolini, G.; Wacharapluesadee, S.; Sungkarat, W.; Shuangshoti, S.; Laothamatas, J. Human rabies: Neuropathogenesis, diagnosis, and management. Lancet Neurol. 2013, 12, 498-513. [CrossRef]

33. Mitrabhakdi, E.; Shuangshoti, S.; Wannakrairot, P.; Lewis, R.A.; Susuki, K.; Laothamatas, J.; Hemachudha, T. Difference in neuropathogenetic mechanisms in human furious and paralytic rabies. J. Neurol. Sci. 2005, 238, 3-10. [CrossRef] [PubMed]

34. Warrell, M.J.; Warrell, D.A. Rabies: The clinical features, management and prevention of the classic zoonosis. Clin. Med. 2015, 15, 78-81. [CrossRef] [PubMed]

35. Piccinotti, S.; Whelan, S.P. Rabies internalizes into primary peripheral neurons via clathrin coated pits and requires fusion at the cell body. Plos Pathog. 2016, 12, e1005753. [CrossRef] [PubMed]

36. Bauer, A.; Nolden, T.; Schröter, J.; Römer-Oberdörfer, A.; Gluska, S.; Perlson, E.; Finke, S. Anterograde glycoprotein-dependent transport of newly generated rabies virus in dorsal root ganglion neurons. J. Virol. 2014, 88, 14172-14183. [CrossRef] [PubMed]

37. Sundaramoorthy, V.; Green, D.; Locke, K.; O’Brien, C.M.; Dearnley, M.; Bingham, J. Novel role of sarm1 mediated axonal degeneration in the pathogenesis of rabies. Plos Pathog. 2020, 16, e1008343. [CrossRef] [PubMed] 
38. Préhaud, C.; Mégret, F.; Lafage, M.; Lafon, M. Virus infection switches tlr-3-positive human neurons to become strong producers of beta interferon. J. Virol. 2005, 79, 12893-12904. [CrossRef]

39. Mégret, F.; Prehaud, C.; Lafage, M.; Moreau, P.; Rouas-Freiss, N.; Carosella, E.D.; Lafon, M. Modulation of hla-g and hla-e expression in human neuronal cells after rabies virus or herpes virus simplex type 1 infections. Hum. Immunol. 2007, 68, 294-302. [CrossRef]

40. D'Aiuto, L.; Bloom, D.C.; Naciri, J.N.; Smith, A.; Edwards, T.G.; McClain, L.; Callio, J.A.; Jessup, M.; Wood, J.; Chowdari, K. Modeling herpes simplex virus 1 infections in human central nervous system neuronal cells using two-and three-dimensional cultures derived from induced pluripotent stem cells. J. Virol. 2019, 93, e00111-e00119. [CrossRef]

41. Sadaoka, T.; Schwartz, C.L.; Rajbhandari, L.; Venkatesan, A.; Cohen, J.I. Human embryonic stem cell-derived neurons are highly permissive for varicella-zoster virus lytic infection. J. Virol. 2018, 92, e01108-e01117. [CrossRef]

42. Dawes, B.E.; Gao, J.; Atkins, C.; Nelson, J.T.; Johnson, K.; Wu, P.; Freiberg, A.N. Human neural stem cell-derived neuron/astrocyte co-cultures respond to la crosse virus infection with proinflammatory cytokines and chemokines. J. Neuroinflammation 2018, 15, 315. [CrossRef]

43. Qian, X.; Nguyen, H.N.; Song, M.M.; Hadiono, C.; Ogden, S.C.; Hammack, C.; Yao, B.; Hamersky, G.R.; Jacob, F.; Zhong, C. Brain-region-specific organoids using mini-bioreactors for modeling zikv exposure. Cell 2016, 165, 1238-1254. [CrossRef]

44. Garcez, P.P.; Loiola, E.C.; da Costa, R.M.; Higa, L.M.; Trindade, P.; Delvecchio, R.; Nascimento, J.M.; Brindeiro, R.; Tanuri, A.; Rehen, S.K. Zika virus impairs growth in human neurospheres and brain organoids. Science 2016, 352, 816-818. [CrossRef] [PubMed]

45. Desole, G.; Sinigaglia, A.; Riccetti, S.; Masi, G.; Pacenti, M.; Trevisan, M.; Barzon, L. Modelling neurotropic flavivirus infection in human induced pluripotent stem cell-derived systems. Int. J. Mol. Sci. 2019, 20, 5404. [CrossRef] [PubMed]

46. Muffat, J.; Li, Y.; Omer, A.; Durbin, A.; Bosch, I.; Bakiasi, G.; Richards, E.; Meyer, A.; Gehrke, L.; Jaenisch, R. Human induced pluripotent stem cell-derived glial cells and neural progenitors display divergent responses to zika and dengue infections. Proc. Natl. Acad. Sci. 2018, 115, 7117-7122. [CrossRef] [PubMed]

47. Shen, S.-C.; Shen, C.-I.; Lin, H.; Chen, C.-J.; Chang, C.-Y.; Chen, S.-M.; Lee, H.-C.; Lai, P.-S.; Su, H.-L. Susceptibility of human embryonic stem cell-derived neural cells to japanese encephalitis virus infection. Plos One 2014, 9, e114990. [CrossRef] [PubMed]

48. Tao, Y.; Zhang, S.-C. Neural subtype specification from human pluripotent stem cells. Cell Stem Cell 2016, 19, 573-586. [CrossRef]

49. Takahashi, K.; Yamanaka, S. A decade of transcription factor-mediated reprogramming to pluripotency. Nat. Rev. Mol. Cell Biol. 2016, 17, 183. [CrossRef]

50. Avior, Y.; Sagi, I.; Benvenisty, N. Pluripotent stem cells in disease modelling and drug discovery. Nat. Rev. Mol. Cell Biol. 2016, 17, 170. [CrossRef]

51. Kim, K.; Zhao, R.; Doi, A.; Ng, K.; Unternaehrer, J.; Cahan, P.; Hongguang, H.; Loh, Y.-H.; Aryee, M.J.; Lensch, M.W. Donor cell type can influence the epigenome and differentiation potential of human induced pluripotent stem cells. Nat. Biotechnol. 2011, 29, 1117. [CrossRef]

52. Ohi, Y.; Qin, H.; Hong, C.; Blouin, L.; Polo, J.M.; Guo, T.; Qi, Z.; Downey, S.L.; Manos, P.D.; Rossi, D.J. Incomplete DNA methylation underlies a transcriptional memory of somatic cells in human ips cells. Nat. Cell Biol. 2011, 13, 541. [CrossRef]

53. Bar-Nur, O.; Russ, H.A.; Efrat, S.; Benvenisty, N. Epigenetic memory and preferential lineage-specific differentiation in induced pluripotent stem cells derived from human pancreatic islet beta cells. Cell Stem Cell 2011, 9, 17-23. [CrossRef] [PubMed]

54. Weissbein, U.; Benvenisty, N.; Ben-David, U. Genome maintenance in pluripotent stem cells. J Cell Biol 2014, 204, 153-163. [CrossRef] [PubMed]

55. Lister, R.; Pelizzola, M.; Kida, Y.S.; Hawkins, R.D.; Nery, J.R.; Hon, G.; Antosiewicz-Bourget, J.; O’Malley, R.; Castanon, R.; Klugman, S. Hotspots of aberrant epigenomic reprogramming in human induced pluripotent stem cells. Nature 2011, 471, 68. [CrossRef] [PubMed]

56. Ruiz, S.; Diep, D.; Gore, A.; Panopoulos, A.D.; Montserrat, N.; Plongthongkum, N.; Kumar, S.; Fung, H.-L.; Giorgetti, A.; Bilic, J. Identification of a specific reprogramming-associated epigenetic signature in human induced pluripotent stem cells. Proc. Natl. Acad. Sci. 2012, 109, 16196-16201. [CrossRef] [PubMed] 
57. Dukhovny, A.; Sloutskin, A.; Markus, A.; Yee, M.B.; Kinchington, P.R.; Goldstein, R.S. Varicella-zoster virus infects human embryonic stem cell-derived neurons and neurospheres but not pluripotent embryonic stem cells or early progenitors. J. Virol. 2012, 86, 3211-3218. [CrossRef]

58. Jones, J.C.; Sabatini, K.; Liao, X.; Tran, H.T.; Lynch, C.L.; Morey, R.E.; Glenn-Pratola, V.; Boscolo, F.S.; Yang, Q.; Parast, M.M. Melanocytes derived from transgene-free human induced pluripotent stem cells. J. Investig. Dermatol. 2013, 133, 2104. [CrossRef]

59. Thomson, J.A.; Itskovitz-Eldor, J.; Shapiro, S.S.; Waknitz, M.A.; Swiergiel, J.J.; Marshall, V.S.; Jones, J.M. Embryonic stem cell lines derived from human blastocysts. science 1998, 282, 1145-1147. [CrossRef]

60. Murphy, A.R.; Ghobrial, I.; Jamshidi, P.; Laslett, A.; O’Brien, C.M.; Cameron, N.R. Tailored emulsion-templated porous polymer scaffolds for ipsc-derived human neural precursor cell culture. Polym. Chem. 2017, 8, 6617-6627. [CrossRef]

61. Beers, J.; Gulbranson, D.R.; George, N.; Siniscalchi, L.I.; Jones, J.; Thomson, J.A.; Chen, G. Passaging and colony expansion of human pluripotent stem cells by enzyme-free dissociation in chemically defined culture conditions. Nat. Protoc. 2012, 7, 2029. [CrossRef]

62. Itskovitz-Eldor, J.; Schuldiner, M.; Karsenti, D.; Eden, A.; Yanuka, O.; Amit, M.; Soreq, H.; Benvenisty, N. Differentiation of human embryonic stem cells into embryoid bodies comprising the three embryonic germ layers. Mol. Med. 2000, 6, 88. [CrossRef]

63. Pera, M.F.; Andrade, J.; Houssami, S.; Reubinoff, B.; Trounson, A.; Stanley, E.G.; Ward-van Oostwaard, D.; Mummery, C. Regulation of human embryonic stem cell differentiation by bmp-2 and its antagonist noggin. J Cell Sci 2004, 117, 1269-1280. [CrossRef] [PubMed]

64. Itsykson, P.; Ilouz, N.; Turetsky, T.; Goldstein, R.S.; Pera, M.F.; Fishbein, I.; Segal, M.; Reubinoff, B.E. Derivation of neural precursors from human embryonic stem cells in the presence of noggin. Mol. Cell. Neurosci. 2005, 30, 24-36. [CrossRef] [PubMed]

65. Gerrard, L.; Rodgers, L.; Cui, W. Differentiation of human embryonic stem cells to neural lineages in adherent culture by blocking bone morphogenetic protein signaling. Stem Cells 2005, 23, 1234-1241. [CrossRef]

66. Sonntag, K.C.; Pruszak, J.; Yoshizaki, T.; Van Arensbergen, J.; Sanchez-Pernaute, R.; Isacson, O. Enhanced yield of neuroepithelial precursors and midbrain-like dopaminergic neurons from human embryonic stem cells using the bone morphogenic protein antagonist noggin. Stem Cells 2007, 25, 411-418. [CrossRef] [PubMed]

67. Conti, L.; Pollard, S.M.; Gorba, T.; Reitano, E.; Toselli, M.; Biella, G.; Sun, Y.; Sanzone, S.; Ying, Q.-L.; Cattaneo, E. Niche-independent symmetrical self-renewal of a mammalian tissue stem cell. Plos Biol. 2005, 3, e283. [CrossRef] [PubMed]

68. Sun, Y.; Pollard, S.; Conti, L.; Toselli, M.; Biella, G.; Parkin, G.; Willatt, L.; Falk, A.; Cattaneo, E.; Smith, A. Long-term tripotent differentiation capacity of human neural stem (ns) cells in adherent culture. Mol. Cell. Neurosci. 2008, 38, 245-258. [CrossRef] [PubMed]

69. Yuan, S.H.; Martin, J.; Elia, J.; Flippin, J.; Paramban, R.I.; Hefferan, M.P.; Vidal, J.G.; Mu, Y.; Killian, R.L.; Israel, M.A. Cell-surface marker signatures for the isolation of neural stem cells, glia and neurons derived from human pluripotent stem cells. Plos One 2011, 6, e17540. [CrossRef]

70. Bardy, C.; Van Den Hurk, M.; Eames, T.; Marchand, C.; Hernandez, R.V.; Kellogg, M.; Gorris, M.; Galet, B.; Palomares, V.; Brown, J. Neuronal medium that supports basic synaptic functions and activity of human neurons in vitro. Proc. Natl. Acad. Sci. 2015, 112, E2725-E2734. [CrossRef]

71. Watmuff, B.; Hartley, B.J.; Hunt, C.P.; Fabb, S.A.; Pouton, C.W.; Haynes, J.M. Human pluripotent stem cell derived midbrain pitx3egfp/w neurons: A versatile tool for pharmacological screening and neurodegenerative modeling. Front. Cell. Neurosci. 2015, 9, 104. [CrossRef]

72. Reed, L.J.; Muench, H. A simple method of estimating fifty per cent endpoints. Am. J. Epidemiol. 1938, 27, 493-497. [CrossRef]

73. Rahmadane, I.; Certoma, A.F.; Peck, G.R.; Fitria, Y.; Payne, J.; Colling, A.; Shiell, B.J.; Beddome, G.; Wilson, S.; $\mathrm{Yu}, \mathrm{M}$. Development and validation of an immunoperoxidase antigen detection test for improved diagnosis of rabies in indonesia. Plos Negl. Trop. Dis. 2017, 11, e0006079. [CrossRef] [PubMed]

74. Hardikar, A.A.; Farr, R.J.; Joglekar, M.V. Circulating micrornas: Understanding the limits for quantitative measurement by real-time pcr. J. Am. Heart Assoc. 2014, 3, e000792. [CrossRef] [PubMed]

75. Nadin-Davis, S.A.; Sheen, M.; Wandeler, A.I. Development of real-time reverse transcriptase polymerase chain reaction methods for human rabies diagnosis. J. Med Virol. 2009, 81, 1484-1497. [CrossRef] [PubMed] 
76. Foord, A.; Heine, H.; Pritchard, L.; Lunt, R.; Newberry, K.; Rootes, C.; Boyle, D. Molecular diagnosis of lyssaviruses and sequence comparison of australian bat lyssavirus samples. Aust. Vet. J. 2006, 84, 225-230. [CrossRef] [PubMed]

77. Benjamini, Y.; Krieger, A.M.; Yekutieli, D. Adaptive linear step-up procedures that control the false discovery rate. Biometrika 2006, 93, 491-507. [CrossRef]

78. Virtanen, P.; Gommers, R.; Oliphant, T.E.; Haberland, M.; Reddy, T.; Cournapeau, D.; Burovski, E.; Peterson, P.; Weckesser, W.; Bright, J. Scipy 1.0-fundamental algorithms for scientific computing in python. arXiv 2019, arXiv:1907.10121. [CrossRef]

79. Terpilowski, M. Scikit-posthocs: Pairwise multiple comparison tests in python. J. Open Source Softw. 2019, 4, 1169. [CrossRef]

80. Xiang, J.; Wan, C.; Guo, R.; Guo, D. Is hydrogen peroxide a suitable apoptosis inducer for all cell types? Biomed Res. Int. 2016, 2016. [CrossRef]

81. Yan, X.; Prosniak, M.; Curtis, M.T.; Weiss, M.L.; Faber, M.; Dietzschold, B.; Fu, Z.F. Silver-haired bat rabies virus variant does not induce apoptosis in the brain of experimentally infected mice. J. Neurovirology 2001, 7, 518-527.

82. Morimoto, K.; Hooper, D.C.; Spitsin, S.; Koprowski, H.; Dietzschold, B. Pathogenicity of different rabies virus variants inversely correlates with apoptosis and rabies virus glycoprotein expression in infected primary neuron cultures. J. Virol. 1999, 73, 510-518. [CrossRef]

83. Hooper, D.C. The role of immune responses in the pathogenesis of rabies. J. Neurovirology 2005, 11, 88-92. [CrossRef] [PubMed]

84. Ubogu, E.E.; Callahan, M.K.; Tucky, B.H.; Ransohoff, R.M. Determinants of ccl5-driven mononuclear cell migration across the blood-brain barrier. Implications for therapeutically modulating neuroinflammation. J. Neuroimmunol. 2006, 179, 132-144. [CrossRef] [PubMed]

85. Bartosik-Psujek, H.; Stelmasiak, Z. The levels of chemokines cxcl8, ccl2 and ccl5 in multiple sclerosis patients are linked to the activity of the disease. Eur. J. Neurol. 2005, 12, 49-54. [CrossRef] [PubMed]

86. Dénes, Á.; Humphreys, N.; Lane, T.E.; Grencis, R.; Rothwell, N. Chronic systemic infection exacerbates ischemic brain damage via a ccl5 (regulated on activation, normal $\mathrm{t}$-cell expressed and secreted)-mediated proinflammatory response in mice. J. Neurosci. 2010, 30, 10086-10095. [CrossRef] [PubMed]

87. Marques, R.E.; Guabiraba, R.; Russo, R.C.; Teixeira, M.M. Targeting ccl5 in inflammation. Expert Opin. Ther. Targets 2013, 17, 1439-1460. [CrossRef] [PubMed]

88. Glass, W.G.; Hickey, M.J.; Hardison, J.L.; Liu, M.T.; Manning, J.E.; Lane, T.E. Antibody targeting of the cc chemokine ligand 5 results in diminished leukocyte infiltration into the central nervous system and reduced neurologic disease in a viral model of multiple sclerosis. J. Immunol. 2004, 172, 4018-4025. [CrossRef]

89. Di Prisco, S.; Merega, E.; Milanese, M.; Summa, M.; Casazza, S.; Raffaghello, L.; Pistoia, V.; Uccelli, A.; Pittaluga, A. Ccl5-glutamate interaction in central nervous system: Early and acute presynaptic defects in eae mice. Neuropharmacology 2013, 75, 337-346. [CrossRef]

90. Pittaluga, A. Ccl5-glutamate cross-talk in astrocyte-neuron communication in multiple sclerosis. Front. Immunol. 2017, 8, 1079. [CrossRef]

91. Grassi-Oliveira, R.; Brieztke, E.; Teixeira, A.; Pezzi, J.C.; Zanini, M.; Lopes, R.P.; Bauer, M.E. Peripheral chemokine levels in women with recurrent major depression with suicidal ideation. Rev. Bras. De Psiquiatr. 2012, 34, 71-75. [CrossRef]

92. Musante, V.; Longordo, F.; Neri, E.; Pedrazzi, M.; Kalfas, F.; Severi, P.; Raiteri, M.; Pittaluga, A. Rantes modulates the release of glutamate in human neocortex. J. Neurosci. 2008, 28, 12231-12240. [CrossRef]

93. Campbell, L.A.; Avdoshina, V.; Day, C.; Lim, S.T.; Mocchetti, I. Pharmacological induction of ccl5 in vivo prevents gp120-mediated neuronal injury. Neuropharmacology 2015, 92, 98-107. [CrossRef] [PubMed]

94. Ignatov, A.; Robert, J.; Gregory-Evans, C.; Schaller, H. Rantes stimulates ca2+ mobilization and inositol trisphosphate (ip3) formation in cells transfected with g protein-coupled receptor 75. Br. J. Pharmacol. 2006, 149, 490-497. [CrossRef] [PubMed]

95. Chitu, V.; Gokhan, Ş.; Nandi, S.; Mehler, M.F.; Stanley, E.R. Emerging roles for csf-1 receptor and its ligands in the nervous system. Trends Neurosci. 2016, 39, 378-393. [CrossRef] [PubMed]

96. Funk, K.E.; Klein, R.S. Csf1r antagonism limits local restimulation of antiviral cd8+ $\mathrm{t}$ cells during viral encephalitis. J. Neuroinflammation 2019, 16, 22. [CrossRef] 
97. Akimoto, N.; Ifuku, M.; Mori, Y.; Noda, M. Effects of chemokine (c-c motif) ligand 1 on microglial function. Biochem. Biophys. Res. Commun. 2013, 436, 455-461. [CrossRef]

98. Gomez-Nicola, D.; Valle-Argos, B.; Nieto-Sampedro, M. Blockade of il-15 activity inhibits microglial activation through the nfkb, p38, and erk1/2 pathways, reducing cytokine and chemokine release. Glia 2010, 58, $264-276$. [CrossRef]

99. Liva, S.M.; de Vellis, J. Il-5 induces proliferation and activation of microglia via an unknown receptor. Neurochem. Res. 2001, 26, 629-637. [CrossRef]

100. Fülle, L.; Offermann, N.; Hansen, J.N.; Breithausen, B.; Erazo, A.B.; Schanz, O.; Radau, L.; Gondorf, F.; Knöpper, K.; Alferink, J. Ccl17 exerts a neuroimmune modulatory function and is expressed in hippocampal neurons. Glia 2018, 66, 2246-2261. [CrossRef]

101. Wang, Z.; Li, M.; Zhou, M.; Zhang, Y.; Yang, J.; Cao, Y.; Wang, K.; Cui, M.; Chen, H.; Fu, Z.F. A novel rabies vaccine expressing cxcl13 enhances humoral immunity by recruiting both $\mathrm{t}$ follicular helper and germinal center b cells. J. Virol. 2017, 91, e01956. [CrossRef]

102. Sawant, K.V.; Poluri, K.M.; Dutta, A.K.; Sepuru, K.M.; Troshkina, A.; Garofalo, R.P.; Rajarathnam, K. Chemokine cxcl1 mediated neutrophil recruitment: Role of glycosaminoglycan interactions. Sci. Rep. 2016, 6, 33123. [CrossRef]

103. Lokensgard, J.R.; Mutnal, M.B.; Prasad, S.; Sheng, W.; Hu, S. Glial cell activation, recruitment, and survival of b-lineage cells following mcmv brain infection. J. Neuroinflammation 2016, 13, 114. [CrossRef] [PubMed]

104. Aaronson, D.S.; Horvath, C.M. A road map for those who don't know jak-stat. Science 2002, 296, $1653-1655$. [CrossRef]

105. Platanias, L.C. Mechanisms of type-i-and type-ii-interferon-mediated signalling. Nat. Rev. Immunol. 2005, 5, 375. [CrossRef] [PubMed]

106. Barkhouse, D.A.; Garcia, S.A.; Bongiorno, E.K.; Lebrun, A.; Faber, M.; Hooper, D.C. Expression of interferon gamma by a recombinant rabies virus strongly attenuates the pathogenicity of the virus via induction of type i interferon. J. Virol. 2015, 89, 312-322. [CrossRef] [PubMed]

107. MacGibeny, M.A.; Koyuncu, O.O.; Wirblich, C.; Schnell, M.J.; Enquist, L.W. Retrograde axonal transport of rabies virus is unaffected by interferon treatment but blocked by emetine locally in axons. Plos Pathog. 2018, 14, e1007188. [CrossRef] [PubMed]

108. Faber, M.; Pulmanausahakul, R.; Nagao, K.; Prosniak, M.; Rice, A.B.; Koprowski, H.; Schnell, M.J.; Dietzschold, B. Identification of viral genomic elements responsible for rabies virus neuroinvasiveness. Proc. Natl. Acad. Sci. 2004, 101, 16328-16332. [CrossRef]

109. Reardon, T.R.; Murray, A.J.; Turi, G.F.; Wirblich, C.; Croce, K.R.; Schnell, M.J.; Jessell, T.M.; Losonczy, A. Rabies virus cvs-n2cסg strain enhances retrograde synaptic transfer and neuronal viability. Neuron 2016, 89, 711-724. [CrossRef]

(C) 2020 by the authors. Licensee MDPI, Basel, Switzerland. This article is an open access article distributed under the terms and conditions of the Creative Commons Attribution (CC BY) license (http://creativecommons.org/licenses/by/4.0/). 